\title{
PREPARING FOR 2007: LEGAL AND LEGISLATIVE ISSUES SURROUNDING THE REAUTHORIZATION OF SECTION 5 OF THE VOTING RIGHTS ACT
}

\author{
Jocelyn Benson*
}

\section{INTRODUCTION}

Forty years ago, civil rights activists across the country rejoiced in the passing of the Voting Rights Act ("VRA" or "the Act"). The Act was a crowning achievement of the classical civil rights movement and the culmination of a bloody series of events seeking political empowerment for African-Americans in the United States.

Two primary provisions of the Act are set to expire in 2007, under the watch of one of the most conservative federal governments in our country's history. It is already apparent that civil rights groups and activists must convene a broad coalition from both ends of the political spectrum to ensure that this historic legislation is preserved and the expiring provisions renewed. This article will attempt to identify and discuss the most contentious issues that can be expected to surround the reauthorization of one provision of the Act: Section 5. It will also suggest solutions for the kinds of academic and legislative strategies that could help resolve some of these tensions in an effort to promote a unified reauthorization effort.

Congress has amended the VRA several times since $1965,{ }^{2}$ and in 1982 and 1992, respectively, set 2007 as an expiration date for two critical provisions: Sections 5 and 203. ${ }^{3}$ Section 5, when it was enacted in 1965, was designed as a remedial device aimed at areas with a documented history of discrimination against voters of color. Those areas, which currently include

\footnotetext{
* Assistant Professor, Wayne State University Law School. B.A. Wellesley College, M. Phil. Oxford University, J.D. Harvard Law School.

1. $\quad 42$ U.S.C. $\S \S 1973-1973 \mathrm{e}(2000)$.

2. The VRA was renewed and amended in 1968, 1970, 1975, 1982, and 1992.

3. In 1982, Congress renewed Section 5, a temporary provision, for twenty-five years. The Voting Rights Act Amendments of 1982, Pub. L. No. 97-205, § 1, 96 Stat. 131 (1982). In 1992, Congress extended Section 203, a provision protecting the voting rights of language minorities, for fifteen years. Voting Rights Language Assistance Act of 1992, Pub. L. No. 102-344, 106 Stat. 921 (1992). Both are, therefore, set to expire in 2007.
} 
Alabama, Georgia, Mississippi, Texas, Arizona, and parts of Michigan, New York, and California, ${ }^{4}$ are required to submit all changes to their election laws and procedures to the federal government for "preclearance" prior to or immediately following their enactment. ${ }^{5}$ The federal government, via either the Civil Rights Division of the Justice Department or the District Court for the District of Columbia, evaluates whether the changes will have a "retrogressive" effect on minority electoral power within the jurisdiction. This test, known as the retrogression standard, originated in a 1976 Supreme Court case, Beer v. United States, ${ }^{6}$ in which the Court evaluated a New Orleans redistricting plan that created one majority-minority city council district (out of seven total districts) in a city where African-Americans comprised over half of the voting age population. The Court upheld the plan as non-retrogressive and permissible under Section 5 because it did not reduce the electoral strength of the African-Americans in the city. ${ }^{7}$ The Court's holding in Beer formed the basis for the modern-day preclearance test, which is generally still in effect under the Court's current interpretation of Section $5 .^{8}$

Another provision of the Act set to expire in 2007 is Section 203. ${ }^{9}$ That provision, added to the VRA in 1975, requires jurisdictions with large concentrations of language-minority citizens to provide election materials translated into the voters' native languages. ${ }^{10}$ Today, Section 203 mandates

\footnotetext{
4. The jurisdictions covered by these provisions are defined in 42 U.S.C. $\S 1973 b$ (b) (2000).

5. Submissions are made to either the U.S. Department of Justice or the Federal District Court of D.C.

6. 425 U.S. 130, 141 (1976).

7. Id.

8. For further explanation on the non-retrogression standard see John C. Jeffries, Jr. \& Daryl J. Levinson, The Non-Retrogression Principle in Constitutional Law, 86 CAL. L. Rev. 1211, 1213 (1998) (noting that under Section 5's retrogression standard, "[e]ven the most burdensome of arrangements can remain in place if they predate the Act or a particular jurisdiction's inclusion in the coverage of the Act. Section 5 forbids only changes that would make minority success less likely.").

9. $\quad 42$ U.S.C. $\$ 1973 a a-1 a(2000)$.

10. In 1992, Congress extended these provisions until 2007. Voting Rights Language Assistance Act of 1992, Pub. L. No. 102-344, 106 Stat. 921 (1992). As amended in 1992, Section 203 of the Voting Rights Act of 1965 reads:

The Congress finds that, through the use of various practices and procedures, citizens of language minorities have been effectively excluded from participation in the electoral process. Among other factors, the denial of the right to vote of such minority group citizens is ordinarily directly related to the unequal educational opportunities afford them, resulting in high illiteracy and low voting participation. . . Before August 6, 2007, no covered State or political subdivision shall provide voting materials only in the English language ... if the Director of the Census determines, based on census data, that-(i)(I) more than five percent of the citizens of voting age of such State or political subdivision are members of a single language minority and are limited-English proficient;
} 
that a state or political subdivision provide language assistance to voters, typically in the form of bilingual ballots and voting instructions in their native language, if over $5 \%$ or more than 10,000 of the voting age citizens in the district are members of one of the single-language minority groups designated in the Section. ${ }^{11}$

The third dominant provision of the VRA, Section 2, is permanent and applies to the entire country. Under Section 2, a private party or the Justice Department can bring a suit to challenge any existing voting practice or apportionment scheme that "results in a denial or abridgment" of the right to vote on the basis of race, color, or language-minority status. ${ }^{12}$ Thus, instead of measuring the impact that a new voting practice will have on existing minority voting strength as required under the retrogression test of Section 5 , Section 2 claims require a court to evaluate the presence or extent of racial vote dilution in a current election procedure. This involves applying a "totality of the circumstances" approach, or examining the overall context of the election systems to determine whether the challenged election law causes minority voters to have "less opportunity than other members of the electorate to participate in the political process and to elect representatives of their choice."13 Additionally, in the context of redistricting schemes challenged under Section 2, the courts have developed three prima facie factors that must be satisfied before a court can determine whether, under a totality of the circumstances, a Section 2 violation has occurred. These preconditions are: (1) the minority group is "sufficiently large and geographically compact to constitute a majority" in a single-member district; (2) the minority group is politically cohesive; and (3) the white majority votes sufficiently as a bloc to enable it usually to defeat the minority-preferred candidate. ${ }^{14}$ If these

(II) more than 10,000 of the citizens of voting age of such political subdivision are members of a single language minority and are limited-English proficient; or (III) in the case of a political subdivision that contains all or any part of an Indian reservation, more than 5 percent of the American Indian or Alaska Native citizens of voting age within the Indian reservation are members of a single language minority and are limited-English proficient; and (ii) the illiteracy rate of the citizens in the language minority as a group is higher than the national illiteracy rate. 42 U.S.C. $§ 1973$ aa-1a (2000).

11. 42 U.S.C. $\S 1973$ aa-1a (2000). These are limited to eight language minority groups: Hispanic, Chinese, Filipino, Japanese, Korean, Vietnamese, American Indian, and Native Alaskan. Two years after the completion of each decennial census, the Director of the Bureau of the Census publishes a revised list of areas covered under Section 203. For the most recent list of covered areas, see Voting Rights Act Amendments of 1992, Determinations Under Section 203, 67 Fed. Reg. 48871-77 (July 26, 2002).

12. 42 U.S.C. $\S 1973$ (a) (2000).

13. 42 U.S.C. $\S 1973($ b) $(2000)$.

14. Thornburg v. Gingles, 478 U.S. 30, 50-51 (1986). See also Voinovich v. Quilter, 507 U.S. 146, 
conditions are met, the Court has sometimes ordered the creation of majorityminority districts to "ensure equal political and electoral opportunity" to minority voters. ${ }^{15}$

As the 2007 reauthorization deadline approaches, the time is ripe to begin examining the issues surrounding the renewal of Sections 5 and 203 - that is, whether they should be renewed and, if so, how they can be amended and strengthened. The foregoing discussion will attempt to provide an overview of the debates over whether to renew and how to strengthen Section 5, and the arguments that can be anticipated on either side. In particular, it will address two levels of debate surrounding the reauthorization of Section 5. It will first delve into the general arguments and concerns surrounding the reauthorization of Section 5, touching on potential federalism or states' rights issues and concerns held by many, including U.S. Supreme Court Justice Anthony Kennedy, over its constitutionality. It will then discuss the issues of contention among those who believe in the reauthorization, but differ over what a reauthorized Section 5 should look like. This discussion will also offer specific suggestions for further research that can potentially resolve some of those contentions.

The first level of debate, discussed in Part II, details concerns among a broader community of interested legislators, election law specialists and attorneys who question the general need for reauthorizing Section 5. ${ }^{16}$ These arguments entail questions of whether sufficient discrimination remains to justify such a broad intrusion into a state or local jurisdiction's election law and procedural decisions. These critiques have been bolstered by current Supreme Court jurisprudence mandating that legislation passed in furtherance of the Equal Protection Clause be "congruent and proportional" to the remedy it is seeking to address. ${ }^{17}$ In other words, the Supreme Court has said that Congress can only enact laws like Section 5, aimed at preventing violations of the Fourteenth and Fifteenth Amendments, if the federal intrusion into state lawmaking is just enough to prevent the recurrence of specific discriminatory acts and enable the remedy of previous ones.

157 (1993); Growe v. Emison, 507 U.S. 25, 40 (1993).

15. Johnson v. De Grandy, 512 U.S. 997, 1019 (1994) (finding that the remedy for a Section 2 violation is race-conscious districting and that, by proving their Section 2 claim, plaintiffs show that "racial and ethnic cleavages ... necessitate majority-minority districts to ensure equal political and electoral opportunity").

16. See generally the writings of Richard Pildes, Carol Swain, and Sam Issacharoff.

17. See City of Boerne v. Flores, 521 U.S. 507 (1997). See discussion infra accompanying notes 75-103. 
Part III will cover the second level of debate surrounding the renewal of Section 5, which assumes agreement that this provision is still relevant and necessary to prevent the enactment of electoral procedures and structures that harm the influence of minority voters. It will discuss current contentions among voting rights advocates and academics who collectively support the reauthorization of Section 5 but disagree on what form the renewed Section 5 should take. These issues specifically deal with clarifying which election laws and apportionment plans should pass preclearance and which should be rejected. Among other things, there are questions over whether apportionment plans that eliminate majority-minority districts should be deemed retrogressive (current case law suggests not ${ }^{18}$ ) and whether election laws and districting that violate Section 2 should be pre-cleared under Section 5 (current case law suggests that violations of Section 2 are not enough to require rejection of a plan or proposed change under Section $5^{19}$ ). The paper will conclude with a few recommendations for further research that can illuminate answers to these and other questions leading up to the reauthorization.

Prior to expanding on both of these debates, however, it is important to detail the development of the current legal and political application of Section 5. The first section will offer an overview of the legislative development and case law surrounding Section 5.

\section{A Brief Overview of the Legal and Political History of Section 5}

When Section 5 was enacted along with the VRA in 1965, it was not seen as one of the Act's most important - or controversial—provisions. ${ }^{20}$ Its original purpose was to prevent state legislatures from enacting a continuous stream of discriminatory voting plans without giving minority plaintiffs an opportunity to challenge those plans through the legal system. ${ }^{21}$ The actual terms in the legislation and the Congressional Record illustrate a great deal of ambiguity over how Section 5 was intended to be implemented and how

18. See Georgia v. Ashcroft, 123 S. Ct. 2498 (2003).

19. See Reno v. Bossier Parish Sch. Bd., 520 U.S. 471 (1997) [hereinafter Bossier Parish I].

20. See Scott Gluck, Congressional Reaction to Judicial Construction of Section 5 of the Voting Rights Act of 1965, 29 Colum. J.L. \& Soc. Probs. 337, 383 (1996) (noting that Section 5 "was not originally considered one of the Act's major provisions and received little attention during the 1965 hearings and floor debate").

21. H.R.ReP.No. 94-196, at 57-58 (1964) ("Section 5 was a response to a common practice in some jurisdictions of staying one step ahead of the federal courts by passing new discriminatory voting laws as soon as the old ones had been struck down."). 
violations were to be determined by the Department of Justice. ${ }^{22}$ Indeed, because at the time most of the discussion was about barriers to the registration of Black voters, state legislatures did not have any significant Black vote to dilute or gerrymander. ${ }^{23}$ Thus, based in part on the context of the times, there is little in the 1965 Congressional Record that discusses which election laws, procedures, and apportionment plans should be rejected under the preclearance provision. ${ }^{24}$

Section 5 was up for reauthorization five years later, in 1970. This first reauthorization occurred under the watch of a hostile White House. The Nixon Administration was pushing for the Section to be repealed, and thenAttorney General John Mitchell sought to replace Section 5 with language authorizing the Department of Justice to initiate a suit anywhere in the country against a discriminatory voting practice. ${ }^{25}$ Despite these attempts, a Democratic-controlled Congress rejected all attempts to repeal or weaken Section 5, and instead reauthorized it for five additional years. Congress also increased the number of jurisdictions subject to preclearance ${ }^{26}$ and, after holding a number of hearings, implicitly acquiesced to the Supreme Court's

22. See Gluck, supra note 20, at 347-57 for further discussion of the ambiguities left by the 1965 legislative record.

23. Id. at 345-46 ("During most of the debate the discussion centered upon eliminating these barriers to Black registration. Given the low registration numbers of Blacks, the 1965 Voting Rights Act was originally and primarily aimed at eliminating obstacles to Black registration, such as literacy tests, good character tests, the practice of purging Blacks from the voting rolls once they were registered, and poll taxes. With all of these impediments to Black registration in place, Southern legislatures had never before needed to resort to schemes aimed at diluting the Black vote; there was, quite simply, no significant Black vote to dilute.").

24. Id. at 346 ("In the few times that Section 5 is mentioned during the [1965 House] congressional hearings and Congressional Record, there is a great deal of ambiguity and conflicting testimony regarding its intended purview."); $i d$. at 352 ("Section 5 was mentioned even less during the Senate hearings than in the House hearings."). See also id. at $352 \mathrm{n} .64$ ("As was the case with the House Hearings, the majority of the discussion in the Senate focused on the constitutionality of the Voting Rights Act, as well as its major and more controversial provisions. As with the House hearings, when Section 5 was mentioned, often times only a mere repetition of the wording of the Act itself was given, which is of little evidentiary value.").

25. See Laughlin McDonald, The 1982 Extension of Section 5 of the Voting Rights Act of 1965: The Continued Need for Preclearance, 51 TENN. L. REv. 1, 63 (1983) (noting also that this amendment failed because Congress "concluded that the Attorney General already had such authority under Section 2 and refused to abandon Section 5 in favor of a return to the ineffective case-by-case method of enforcing voting rights").

26. The added jurisdictions were: Kings and Bronx Counties in New York; Elmore County, Idaho; election districts in Alaska; counties in Arizona, California, and Wyoming; and towns in Connecticut, New Hampshire, Maine, and Massachusetts. S. ReP. No. 94-295, at 13 (1975). 
reading of Section 5 to require preclearance of all electoral changes in a covered district, not just those relating to voting. ${ }^{27}$

In 1975, Congress made permanent the provision of the Act that outlawed the application of literacy tests and other voting qualifications. ${ }^{28}$ It also extended preclearance for an additional seven years, ${ }^{29}$ enlarged the number of areas covered by Section $5,{ }^{30}$ and extended protection to "language minorities." ${ }^{\prime 31}$ The following year, the Justice Department received its greatest number of submissions to date, nearly 7,500, in part due to the extension of Section 5 to include Texas. ${ }^{32}$ The 1975 changes and the extension were reviewed and upheld as constitutional by the U.S. Supreme Court in $1980 .{ }^{33}$

The Supreme Court issued its most far-reaching interpretation of Section 5 in the year following the 1975 reauthorization. In Beer v. United States, ${ }^{34}$ the Court adopted a non-retrogression principle to govern preclearance

27. See Allen v. State Bd. of Elections, 393 U.S. 544, 566 (1969) (interpreting Section 5 to include any electoral changes rather than only those changes involving the act of voting itself, thus ensuring that virtually every change relating to the voting process, regardless of how minor, had to be cleared in Washington before it could be implemented). See also Gluck, supra note 20, at 360-71 (discussing Congress's decision not to respond to or otherwise overrule the Court's decision in Allen as indicating acceptance of the Court's interpretation).

28. Voting Rights Act Amendments of 1975, Pub. L. No. 94-73, 89 Stat. 402 (1975) (codified as amended at 42 U.S.C. $\S 1973$ (a) (2000)). The original suspension of literacy tests was held to be constitutional in South Carolina v. Katzenbach, 383 U.S. 301, 334 (1966), and Oregon v. Mitchell, 400 U.S. 112, 132 (1970).

29. Voting Rights Act Amendments of 1975, Pub. L. No. 94-73, §§14(c)(3), 207, 89 Stat. 401, 402 (1975) (codified as amended at 42 U.S.C. § 1973l(c)(3) (2000)).

30. Jurisdictions added to Section 5 coverage include Alaska ("recaptured" after a successful bailout from original coverage), Arizona, and various counties in California, Florida, Michigan, South Dakota, Texas, North Carolina, Colorado, Idaho, and Hawaii. See 28 C.F.R. § 51 app. (1976).

31. Language minorities were defined as American Indians, Asian Americans, Alaskan Natives and Hispanics. 42 U.S.C. § 1973aa-1 a(e) (2000). The term "test or device" for purposes of Section 5 coverage was amended to include English-only registration procedures and elections where a single linguistic minority comprises more than $5 \%$ of the voting age population in the jurisdiction. Voting Rights Act Amendments of 1975, Pub. L. No. 94-73, § 203, 89 Stat. 400, 401-02 (codified as amended at 42 U.S.C. $\S 1973 b(f)(3)(2000))$.

32. See McDonald, supra note 25, at 64-65 ("The greatest number of submissions-7,472-were made in 1976, when Congress, with the 1975 amendments to the Act, made Texas a covered jurisdiction pursuant to Section 5. In 1980 there were 7,340 submissions."). McDonald's 1983 research also revealed that, "[f]rom 1965 through 1980, there were approximately 35,000 changes in voting submitted for preclearance to the Department of Justice. As of February 1981, the Department found 815 changes objectionable." Id. at 65 .

33. City of Rome v. United States, 446 U.S. 156, 182 (1980) (holding the 1975 extension of Section 5 constitutional and stating that "Congress' considered determination that at least another 7 years of statutory remedies were necessary to counter the perpetuation of 95 years of pervasive voting discrimination is both unsurprising and unassailable").

34. 425 U.S. 130 (1976). 
reviews of the "effects" of electoral changes. Specifically, the Court held that a covered jurisdiction was not obligated to maximize the political strength of minority voters, but only "to insure that no voting procedure changes would be made that would lead to a retrogression in the position of racial minorities with respect to their effective exercise of the electoral franchise. ${ }^{\prime 35}$ Thus, any electoral change that led to a decrease in the minority's "effective exercise" of its voting strength would be held to violate the VRA. In Beer, the Court upheld the legality of a redistricting plan that slightly improved the chances of minority voters electing their candidate of choice over the previous plan, even though it did not maximize, or even significantly improve, those chances. $^{36}$

The "non-retrogression" holding in Beer was a significant move away from the Court's previously broad interpretations of the VRA. Scholars have called it "the foot in the door for the Rehnquist Court's color-blind jurisprudence and the subsequent death of minority voting rights" ${ }^{\prime 37}$ and a "bittersweet decision for minority voters." 38 But while the Beer decision focused on the minimal requirements that a jurisdiction must adhere to in order to comply with Section 5, a case decided the following year represented a higher point of the Court's interpretation of the VRA. In United Jewish Organizations, Inc. v. Carey" ("UJO"), the Court held that the Constitution did not prevent a jurisdiction that was covered by Section 5 from deliberately creating or maintaining minority-majority districts in order to insure that a reapportionment plan satisfies the Section, particularly when the jurisdiction was attempting to eradicate the effects of past discrimination. ${ }^{40}$

Congress strengthened the protections of Section 5 again in 1982 by extending it another twenty-five years, setting it to expire in $2007 .{ }^{41}$ That year, Congress also established a new scheme for bailout from Section 5 coverage designed to encourage jurisdictions to change their voting practices

35. Id. at 141 .

36. For an extensive description of the Beer case, see, e.g., Lindsay Errickson, Threading the Needle: Resolving the Impasse Between Equal Protection and Section 5 of the Voting Rights Act, 54 VAND. L. REv. 2057, 2062-65 (2001).

37. Virginia E. Hench, The Death of Voting Rights: The Legal Disenfranchisement of Minority Voters, 48 CASE W. RES. L. REV. 727, 752 (1998).

38. Jason Watkins, Mississippi's 2002 Congressional Reapportionment: Legislators BewareEliminating a Minority Influence District May Violate the Nonretrogression Principle of the Voting Rights Act, 69 Miss. L.J. 885, 890 (1999).

39. 430 U.S. 144 (1977).

40. Id. at 161 .

41. Voting Rights Act Amendments of 1982, Pub. L. No. 97-205, § 2, 96 Stat. 131, 133 (1982). 
and thereby eliminate barriers to minority political participation. A jurisdiction could "bailout" of the preclearance requirements by seeking a declaratory judgment from a three-judge panel of the District Court of the District of Columbia, showing it had met the bailout requirements for a tenyear period. ${ }^{42}$ These bailout requirements include: (1) full compliance with the preclearance requirements; (2) a demonstration that no test or device had been used to discriminate on the basis of race, color, or language; (3) a showing that no actions alleging voting discrimination are pending. ${ }^{43}$

Following the 1982 amendments, the Justice Department took an aggressive stance in enforcing Section 5, leading to the adoption of a record number of majority-minority districts in covered areas where over $50 \%$ of the voting age population was a member of a racial minority group. ${ }^{44}$ This led to a reaction from the courts, and an amalgamation of cases that together greatly weakened the strength of Section 5's preclearance "shield." In 1993, the Court issued its opinion in Shaw v. Reno ${ }^{45}$ and held that the Equal Protection Clause of the Fourteenth Amendment would not permit an election law or redistricting plan that, though non-retrogressive, goes "beyond what [is] reasonably necessary to avoid retrogression. ${ }^{, 46}$ In particular, the Court in Shaw barred the use of race as a predominant factor in redistricting schemes. ${ }^{47}$ And in Miller v. Johnson, ${ }^{48}$ the Court overturned a districting plan that was created to comply with Section 5, stating that one or more of the minority districts in it were created primarily with a racial motive. ${ }^{49}$

However, one year later in Bush v. Vera, ${ }^{50}$ the Court noted that the nonretrogression principle of Section 5 "mandates that the minority's opportunity to elect representatives of its choice not be diminished, directly or indirectly,

42. Id. (codified at 42 U.S.C. $\S 1973$ b(a) (2000)). Several jurisdictions quickly took advantage of the provision. Within five years of its enactment, the state of Alaska, along with counties in Arizona and North Carolina, bailed out of coverage. The Attorney General, who consented to the bailouts, found that for the five years prior to their respective lawsuits, each jurisdiction "had not used a voting test or device with a racially discriminatory purpose or effect." Paul F. Hancock \& Lora L. Tredway, The Bailout Standards of the Voting Rights Act: An Incentive to End Discrimination, 17 URB. LAw. 379, 392 (1985).

43. See 42 U.S.C. $\S 1973 b(a)$.

44. See Bernard Grofman \& Lisa Handley, 1990s Issues in Voting Rights, 65 Miss. L.J. 205, 208 (1995) ("[T] he number of majority black districts in the South increased from 4 in 1990 to 18 in 1992, and 17 of these new districts elected African-Americans to office. These districts, incidentally, were the only districts in the South to elect African-Americans to Congress.").

45. 509 U.S. 630 (1993).

46. Id. at 655 .

47. Id. at $657-58$.

48. 515 U.S. $900(1995)$

49. Id. at 917-20.

50. 517 U.S. 952 (1996). 
by the State's actions." ${ }^{.51}$ Specifically the Court's opinion in Vera provides that "so long as [states] do not subordinate traditional districting criteria to the use of race for its own sake or as a proxy, States may intentionally create majority-minority districts, and may otherwise take race into consideration, without coming under strict scrutiny." ${ }^{2} 2$ The Court did not overrule its previous jurisprudence; however, the opinion noted that districts that are bizarrely shaped and non-compact, or that otherwise neglect traditional districting principles and deviate substantially from the hypothetical courtdrawn district for predominantly racial reasons, will still be deemed unconstitutional. ${ }^{53}$

This redistricting conundrum was further complicated by the two landmark decisions in Reno v. Bossier Parish School Board. ${ }^{54}$ In 1997, the Court held in Bossier Parish I that preclearance may not be denied solely on the basis that the election change would violate Section 2 of the VRA. ${ }^{55}$ The Court held that evidence that a change would violate Section 2 may be relevant to prove that a covered jurisdiction had retrogressive intent in enacting a redistricting plan or other electoral change with a discriminatory purpose, but emphasized that "the link between dilutive impact and intent to retrogress is far from direct." 56 Two years later, in Bossier Parish II, the Court held that a redistricting plan with a "discriminatory but nonretrogressive" purpose would not violate Section $5 .{ }^{57}$ In other words, a proposed voting change that, despite evidence of purposeful discrimination, still manages to improve or maintain the status quo with respect to the electoral influence of minority voters would be permissible. In Bossier Parish $I I$, this meant specifically that a jurisdiction where $20 \%$ of its voters were black, with a decades-long history of resistance to school desegregation orders, was not required to draw any majority-black districts for its school board. ${ }^{58}$ Section 5, the Court interpreted, "prevents nothing but backsliding, and preclearance under [Section 5] affirms nothing but the absence of

51. Id. at 983 (emphasis in original omitted).

52. Id. at 993 (O'Connor, J., concurring).

53. Id. at 994 (O'Connor, J., concurring).

54. Bossier Parish I, 520 U.S. 471 (1997), and Reno v. Bossier Parish Sch. Bd., 528 U.S. 320 (1999) [hereinafter Bossier Parish II].

55. For discussion of Section 2 claims, see supra notes 12-15 and accompanying text.

56. Bossier Parish I, 520 U.S. at 487.

57. 528 U.S. at 341.

58. For further discussion on the history and facts of Bossier Parish I and II, see, e.g., Charlotte Marx Harper, A Promise for Litigation: Reno v. Bossier Parish School Board, 52 BAYLOR L. Rev. 647 (2000). 
backsliding." 59 In its constitutional argument, the Court warned that extending Section 5 to prohibit districting plans with "discriminatory but nonretrogressive vote-dilutive purposes ... would also exacerbate the 'substantial' federalism costs that the preclearance procedure already exacts, perhaps to the extent of raising concerns about [Section] 5's constitutionality. ${ }^{\prime 60}$

Bossier Parish I and II were perhaps the Supreme Court's strongest blows to the strength of Section 5. ${ }^{61}$ By removing a discrimination prong from the preclearance evaluation, the Court limited the federal government's power to deny preclearance only in situations where a plan was retrogressive in purpose or effect.

This limit was exacerbated even further in 2003. In Georgia v. Ashcroft $t^{62}$ ("Georgia"), the Supreme Court narrowed the scope of what changes to election laws and procedures could be found to be retrogressive, dramatically altering the established legal test for evaluating whether certain election laws had a harmful effect on minority voters. ${ }^{63}$ The central question faced by the Supreme Court in Georgia was whether the Georgia State Senate districting plan, drawn by the state legislature following the 2000 census, had a retrogressive effect on African-American voting strength. ${ }^{64}$ The Court held that, despite the fact that the new districting plan reduced the number of majority-minority districts in the state, Georgia "likely met its burden of showing non-retrogression" because Section 5 allows states the flexibility to

59. Bossier Parish II, 528 U.S. at 335.

60. Id. at 336 (internal citations omitted).

61. See, e.g., Alaina C. Beverly, Lowering the Preclearance Hurdle, 5 Mich. J. Race \& L. 695, 710 (2000) (warning that "the holding of Bossier Parish II entrenches the status quo and effectively reads the purpose prong out of Section 5 of the Voting Rights Act. In the future, this case will place the burden upon challengers of preclearance to prove retrogression or to use avenues other than Section 5 to make a claim that a redistricting plan is discriminatory. Armed with the circumscribed reading of purpose in Bossier Parish II, jurisdictions will probably look to the District of Columbia District Court for vindication, making it easier for covered jurisdictions to bound over the one-time nearly insurmountable hurdle of Section 5."); J. Gerald Hebert, Redistricting in the Post-2000 Era, 8 GEo. MASOn L. REv. 431, 444 (2000) (concluding that "redistricting plans enacted with an unconstitutional, racially discriminatory but non-retrogressive purpose will now receive preclearance from the DOJ and then be subject to immediate challenge in the courts. This result is plainly at odds with the prophylactic purposes of section 5 , which Congress intended to place the burdens of time and inertia on the shoulders of the perpetrators of discrimination rather than the victims.").

62. 123 S. Ct. 2498 (2003).

63. See, e.g., Pamela S. Karlan, Georgia v. Ashcroft and the Retrogression of Retrogression, 3 Election L.J. 21, 21 (2004) ("The Court's opinion [in Georgia] fundamentally alters the preclearance process in disturbing ways.").

64. Georgia, 123 S. Ct. at 2504. 
reduce the minority voting age population in some majority-minority districts "even if it means that in some of those districts, minority voters will face a somewhat reduced opportunity to elect a candidate of their choice." 65

Georgia's plan "unpacked" many of the state's majority-minority legislative districts and replaced them with a number of influence districts. ${ }^{66}$ Yet, although the new plan reduced the overall number of majority-minority districts, the Court found that the Georgia State Senate plan did not "lead to a retrogression in the position of racial minorities with respect to their effective exercise of the electoral franchise" because it created more majorityDemocrat districts. ${ }^{67}$ Based on the reasoning that an elected Democrat was more likely to represent the interests of black voters than a Republican, regardless of her race or the demographics of her supporters, the Court reasoned that the legislature's intent in drawing these district lines to create majority-Democrat districts protected the interests of black voters in Georgia. ${ }^{68}$ The Court's opinion emphasized that "a substantial majority of black voters in Georgia" are registered Democrats and noted that numerous African-American elected officials in Georgia-all of whom were Democrats-supported the challenged plan. ${ }^{69}$

The Supreme Court's opinion in Georgia dramatically weakened the strength of Section 5 by essentially increasing the types of redistricting changes that are permissibly non-retrogressive. Whereas previous opinions by the Court had described Section 5 as a federal protection against state and local efforts to diminish the ability of communities of color to elect

65. Id. at $2515-16$.

66. Id. at 2506 . This unpacking is even more problematic because minority constituencies generally have lower voter participation rates than white constituencies. Thus, the ratio of registered voters is typically even more stark. A district where $40 \%$ of the voting age population is black could also be a district where only $20 \%$ of the registered voters are black. See Bernard Grofman et al., Drawing Effective Minority Districts: A Conceptual Framework and Some Empirical Evidence, 79 N.C. L. REv. 1383, 1404-05 (2001) [hereinafter Drawing Effective Minority Districts].

67. Georgia, 123 S. Ct. at 2504 (citing Beer v. United States, 425 U.S. 130, 141 (1976)); Georgia, $123 \mathrm{~S}$. Ct. at 2516. It is worth noting, however, that the first election held under the new districting plan led to a decrease in the number of Democrats who were elected to the State Senate. The Democrats lost 7 seats in the Georgia State Senate to the Republicans in 2004. Compare Georgia Secretary of State, http://www.sos.state.ga.us/elections/election_results/2002_1105/senate.htm (indicating that in 2002, 29 Democrats and 27 Republicans were elected to the Georgia State Senate), with Georgia Secretary of State, Official Results of the November 2, 2004 General Election, at http://www.sos.state.ga.us/elections/ election_results/2004_1102/senate.htm (indicating that in 2004, 22 Democrats and 34 Republicans were elected to the Georgia State Senate).

68. Georgia, 123 S. Ct. at 2506.

69. Id. at 2505 . 
representatives of their choice,$^{70}$ the Court's holding in Georgia departed from that precedent and promoted greater deference to the covered jurisdictions, despite the fact that those jurisdictions are covered by Section 5 precisely because they have previously instituted policies that weakened the electoral power of minority voters. Under the new standard, a court's federal review must look only at whether, in enacting a new districting plan, (1) the local jurisdiction tried to protect the "ability of minority voters to elect their candidate of choice," (2) whether the minority group currently has an opportunity to participate in the political process, and (3) whether local minority officeholders supported the plan. ${ }^{71}$ If the federal evaluator determines that officials in the covered jurisdiction met these requirements, the plan is permissible under Section 5, even if the plan leads to an overall reduction in the election of minority candidates of choice.

Georgia caps the convoluted evolution of the Court's interpretation of Section 5 as it approaches its 2007 expiration. While some contend that Congress and advocates can take advantage of the upcoming reauthorization deadline to push for a strengthened version of the provision, ${ }^{72}$ others argue that constitutional concerns and a general decrease in discrimination in the covered areas indicate that the Section is no longer needed and should be allowed to expire. Thus, before launching into a discussion of the ways Section 5 can be improved in light of today's political climate and Supreme Court jurisprudence, it is important to discuss whether the Section should be reauthorized at all.

\section{General Debates Around Whether to Renew Section 5}

There are three predominant issues raised by academics and others who believe that Section 5 ought to be retired in 2007. First is the constitutional issue - that is, whether Section 5 is still a constitutionally permissible remedy for past electoral discrimination. The second is a related but more general "states' rights" argument as to whether the federal intrusion created by the Section 5 preclearance requirements is still warranted given that even voting rights heroes like Congressman John Lewis have testified that some covered areas are no longer rife with electoral barriers. ${ }^{73}$ Lastly, there is concern that

70. See Bush v. Vera, 517 U.S. 952 (1996).

71. Georgia, 123 S. Ct. at 2511.

72. See, e.g., Jocelyn Benson, Turning Lemons into Lemonade: Making Georgia v. Ashcroft the Mobile v. Bolden of 2007, 39 HARV. C.R.-C.L. L. REV. 485 (2004).

73. Georgia, 123 S. Ct. at 2517. 
Section 5 conflicts with Section 2, making for a confusing VRA where electoral changes could pass muster under one section but be struck down under another. ${ }^{74}$ Proponents of this argument generally believe that Section 2 alone is sufficient for protecting against discriminatory election laws and districting, and that as such, Section 5 should be allowed to expire.

\section{A. The Constitutional Issue}

The most significant hurdle facing Section 5's reauthorization is whether its extension would be constitutional under the Supreme Court's current interpretation of Congressional power to pass legislation in furtherance of the Fourteenth Amendment. ${ }^{75}$ In 1997, the Supreme Court radically revised its Fourteenth Amendment jurisprudence when it struck down the Religious Freedom Restoration Act ("RFRA") in City of Boerne v. Flores. ${ }^{76}$ The Court in Boerne held that, while Congress has the power to "enforce" the Fourteenth Amendment with appropriate legislation, Congress did not have "the power to decree the substance of the Fourteenth Amendment's restrictions on the States." 77 Instead, it is the Court's role to interpret the scope of the Fourteenth Amendment and Congress's role to enact legislation in furtherance of that interpreted scope. While the Constitution gave Congress the "remedial" power to enforce existing constitutional provisions, it barred the passage of legislation that altered the meaning of those provisions. ${ }^{78}$ And with any remedial legislation, the Court declared, there must be "congruence and proportionality between the injury to be prevented or remedied and the means adopted to that end." ${ }^{97}$ Thus, the RFRA was struck down because it went beyond these powers, as it was enacted to combat religious bigotry despite the

74. This argument against the renewal of Section 5 was emphasized by Justice Kennedy in Georgia. Id. (Kennedy, J., concurring).

75. See, e.g., Victor Andres Rodriguez, Section 5 of the Voting Rights Act of 1965 After Boerne: The Beginning of the End of Preclearance?, 91 CAL. L. REv. 769, 796-97 (2003) ("Congress will almost certainly consider Section 5's constitutionality when deliberating an extension of the Act's provisions.... It is likely that both congressional advocates and opponents of extension will use [City of] Boerne and its progeny in debating whether to reauthorize the Act: Advocates could use the cases to design the extension to withstand a legal attack, and opponents could use the cases to strengthen the argument for allowing the Act's provisions to expire.").

76. 521 U.S. 507 (1997).

77. Id. at 519 (emphasis added).

78. Id.

79. Id. at 520 . 
fact that, in the legislative record, there was no evidence of religious persecution "occurring in the past 40 years." 80

Boerne was followed by a series of decisions expanding on the congruence and proportionality test, each of which further narrowed congressional enforcement capacity under the Fourteenth and Fifteenth Amendments. ${ }^{81}$ However, in 2003, the Court moved slightly away from this trend in Nevada Department of Human Resources v. Hibbs. ${ }^{82}$ In Hibbs, the Court upheld a provision of the Family and Medical Leave Act ("FMLA") that permitted state employees to sue the state for violations of the Act's family leave provision. ${ }^{83}$ While reiterating the limits on Congress to substantially redefine the substance of the Fourteenth Amendment, stating that "[t]here must be a congruence and proportionality between the injury to be prevented and remedied and the means adopted to that end," the Hibbs decision gave Congress wide latitude to delineate the line between substance and remedy. ${ }^{84}$

Despite the opinion in Hibbs, the precedent established under Boerne has doomed various pieces of civil rights legislation, ${ }^{85}$ and many, including Justice Kennedy, ${ }^{86}$ have speculated that a reauthorized Section 5 would meet a similar fate. ${ }^{87}$ On one hand, Section 5 has withstood previous constitutional challenges, ${ }^{88}$ and the opinion in Boerne even refers to Section 5 as a permissible extension of Congress's enforcement power. ${ }^{89}$ Further, the Court

80. Id. at 530 .

81. See, e.g., Bd. of Trs. of Univ. of Ala. v. Garrett, 531 U.S. 356, 373-74 (2001) (holding that the ADA properly abrogated the sovereign immunity of the states, but was not enacted based on a sufficient record of unconstitutional discrimination to justify the imposition of the remedy); Kimel v. Fla. Bd. of Regents, 528 U.S. 62, 81 (2000) (reiterating that "[t]he ultimate interpretation and determination of the Fourteenth Amendment's substantive meaning remains the province of the Judicial Branch").

82. 123 S. Ct. $1972(2003)$.

83. Id. at 1984

84. Id. at 1994 (citing Boerne, 521 U.S. at 520).

85. See, e.g., Kimel v. Fla. Bd. of Regents, 528 U.S. 62 (2000); Bd. of Trs. of the Univ. of Ala. v. Garrett, 531 U.S. 356 (2001).

86. Marcia Coyle, Politics, Law Clash in Racial Redistricting, NAT'L L.J., Oct. 31, 1994, at A25 ("Justice Anthony Kennedy has indicated several times that he wants to examine the constitutionality of the Voting Rights Act.").

87. See Charlotte Marx Harper, Lopez v. Monterey County: A Remedy Gone Too Far?, 52 BAYLOR L. Rev. 435, 449-55 (2000) (arguing that Lopez was wrongly decided, and "[t]he application of Section 5 of the VRA to the laws enacted by a non-covered state does not fit within the remedial nature of the Fifteenth Amendment").

88. See City of Rome v. United States, 446 U.S. 156, 180-82 (1980) (holding the 1975 reauthorization of the Section 5 preclearance provisions was constitutional); South Carolina v. Katzenbach, 383 U.S. 301, 337 (1966) ("We here hold that [Section 5] of the Voting Rights Act ... [is] a valid means for carrying out the commands of the Fifteenth Amendment.").

89. Boerne, 521 U.S. at 525-26. 
recently held specifically in Lopez v. Monterey County that "the Voting Rights Act, by its nature, intrudes on state sovereignty. The Fifteenth Amendment permits this intrusion....."90

It does not automatically follow, however, that a reauthorized Section 5 could withstand similar challenges today. Some have argued that the provision has only been upheld thus far because of its sunset clause and that reauthorizing it could render that justification irrelevant. ${ }^{91}$ Without proof of significant efforts to harm the electoral strength of minority voters, and absent evidence that covered areas are continuing to discriminate based on race or national origin, there is a fear that certain Supreme Court Justices would not believe there is a continued need for the preclearance requirements. ${ }^{92}$

To that end, various prominent voting rights scholars have stressed the necessity of building a record of evidence of ongoing racial discrimination in covered jurisdictions. ${ }^{93}$ Such a record could ensure the survival of a renewed Section 5 in the face of a Boerne challenge. Further investigation is needed to determine just how much evidence could be sufficient, particularly with the gradual decline in overt racial discrimination in covered areas. One suggestion is for advocates to present Congress with evidence of racial bloc voting to "function as a proxy for intentional discrimination in some circumstances." $"$ In support of this, one scholar has argued that, overall,

90. 525 U.S. 266, 284-85 (1999).

91. See, e.g., Rodriguez, supra note 75, at 775 ("The time limitation on Section 5 has been one of the main factors distinguishing it from statutory provisions that the Court has recently disapproved. Opponents of Section 5 could argue that Congress's repeated extension of Section 5 renders the time limitation less meaningful.").

92. Harper, supra note 87, at 449-55. See also Paul Winke, Why the Preclearance and Bailout Provisions of the Voting Rights Act are Still a Constitutionally Proportional Remedy, 28 N.Y.U. Rev. L. $\&$ Soc. Change 69, 118 (2003).

Even if Congress were to extend [Section 5] unmodified for a period of years, it would need to demonstrate that the intrusion into state sovereignty represented by the preclearance and bailout procedures continues to be warranted, and hence that Section 5 remains a remedial scheme rather than having been transformed into a substantive interpretation of the Fifteenth Amendment byvirtue of changed historical circumstances. Id.

93. See, e.g., Pamela Karlan, Two Section Twos and Two Section Fives: Voting Rights and Remedies after Flores, 39 WM. \& MARY L. REV. 725 (1998).

94. Winke, supra note 92, at 119.

In those cases where racial bloc voting is severe enough to consistently deny minorities the opportunity to elect representatives of their choice, the acquiescence of election officials in such a process amounts to a form of racial discrimination. While such discrimination may not be intentional in every case, it is reasonable to surmise that inaction or grudging action in the face of racial bloc voting must, in many circumstances, be the result of intentional, and hence unconstitutional, discrimination. 
"[t]he most important elements of any evidence gathered should be a consistent and significant pattern of minority underrepresentation combined with an inadequate governmental response after being apprised of the nature of the problem. ${ }^{.95}$

Pamela Karlan has suggested that the Supreme Court's opinion in Boerne can be interpreted to permit legislation that seeks to provide a remedy for three types of discrimination: internal, external, and prospective. ${ }^{96}$ Evidence of internal discrimination involves a showing of voting practices that are blatantly administered in an intentionally discriminatory manner, such as literacy tests and poll taxes. ${ }^{97}$ Evidence of external discrimination involves the presence of election procedures and apportionment plans that are facially neutral but have a disparate, harmful impact on minority voters. ${ }^{98}$ Prospective discrimination evidence includes examples of current voting practices that could lead to future discrimination to minority voters, such as attempts to pass redistricting plans that exclude or harm the electoral power of minority voters. ${ }^{99}$ By including evidence of these three types of discrimination in the legislative record, Karlan argues a renewed Section 5 should withstand constitutional scrutiny. ${ }^{100}$

In addition to evidentiary considerations like Karlan's, the civil rights world must focus on developing legislative strategies to combat potential constitutionality pitfalls. Victor Rodriguez, an attorney with the Mexican American Legal Defense Fund ("MALDEF"), has cogently presented three of the most prominently discussed legislative strategies: (1) maintaining the temporary nature of the provision by limiting its renewal to under twenty-five years $;{ }^{101}(2)$ weakening the bailout provision to make it easier for jurisdictions

Id.

95. Id.

96. Karlan, supra note 93 , at $728-40$.

97. Id. at 733-38.

98. Id. at 738 ("In assessing the constitutionality of Congress's determination to enforce the Fourteenth and Fifteenth Amendments using an impact standard, the Court should conclude that the risk that constitutionally innocuous conduct will be banned is outweighed by the difficulty of detecting and stopping serious constitutional injuries."). An example of this is the disparate spread of spoiled ballots in the 2000 Presidential Election. See Christopher Edley, Jr. et al., Harvard Civil Rights Project, Democracy Spoiled: National, State, and County Disparities in Disenfranchisement Through UnCounted BALlots 8 (2002) (finding that, in the general election of November 2000, counties with Black voting-age populations above the national average of $12 \%$ had a higher average spoiled ballot rate than counties where the voting-age population was less than $12 \%$ Black).

99. Id. at 740 .

100. Id. at 741 .

101. Rodriguez, supra note 75 , at 805 ("Congress should consider maintaining a sunset provision that limits the length of the reauthorization because such a provision has been one of the key characteristics 
to opt out of coverage; ${ }^{102}$ and (3) reducing the number of areas covered under Section 5 to those jurisdictions that were only recently denied preclearance. ${ }^{103}$

While the first of these is reasonable given the importance the Supreme Court grants to Section 5's sunset clause in Boerne, the strategy of pushing for a temporary Section 5 can hardly be considered sufficient to overcome the evidentiary concerns facing the reauthorization. The second suggestion, weakening the opt-out provision, would also not stand on its own to promote reauthorization without accompanying evidence of current continuing discrimination in jurisdictions that would remain covered.

The final suggestion does address that issue, but does so at the risk of weakening the overall strength of the provision and the VRA. If Congress were to reduce the number of areas covered by Section 5 to only those that have proposed electoral changes that violated the preclearance provision in the past twenty years, the VRA protections would fall victim to the tenuous assumption that a jurisdiction that has not proposed any retrogressive electoral changes in the past twenty years, but had in the past twenty-five, would not do so in the future.

If, however, any of these strategies are coupled with an effort to present evidence of discriminatory electoral practices in other areas, they could present potential bargaining concessions if the debate remains strictly focused on whether to reauthorize the provision. Still, it is worth emphasizing that they should not be considered a "starting point" for a legislative strategy employed by advocates wishing to remain focused on reauthorizing a strong and effective Section 5.

\section{B. The Federalism Issue}

Beyond the constitutional issues lie deeper federalism and states' rights concerns about the intrusion of federal anti-discrimination review standards on state or local election procedures. ${ }^{104}$ Whether or not the Supreme Court

distinguishing Section 5 from disapproved statutes. The length of the reauthorization period may also be a significant factor. . . . [T] he first three reauthorization periods were relatively short (1965-1970, 1970-1975, and 1975-1982) while the most recent reauthorization was for twenty-five years.").

102. Id. at 806 .

103. Id. at 805-06.

104. Id. at 803 ("Federalism concerns will undoubtedly drive most of the opposition to the Act's extension."); see also Winke, supra note 92, at 85 ("Section 5 of the Voting Rights Act represents the most powerful intrusion into state and local sovereignty of the civil rights legislation passed in the postwar period."). 
agrees that such an imposition violates the Constitution, ${ }^{105}$ critics argue that Section 5's preclearance requirement imposes substantial and even unnecessary federalism costs on covered jurisdictions seeking to, in many cases, merely draw their own district lines or enact certain election procedures. ${ }^{106}$ Of specific concern is that federal enforcement of Section 5 preempts jurisdictions from enacting their own voting changes and apportionment plans, instead requiring that they receive approval from the U.S. Department of Justice ("DOJ") or a federal court in Washington, DC. A secondary and related concern is that the jurisdictions must then bear the burden of proving that any proposed change does not discriminate against minority voters, instead of placing that burden on the federal government.

These federalism concerns were highlighted in recent court opinions. In Lopez v. Monterey County, ${ }^{107}$ the U.S. Supreme Court was asked whether Monterey County, a California county covered by Section 5, was required to preclear an election change imposed by the California state government, when the state as a whole was not covered by Section 5. The Court held that a covered jurisdiction within a non-covered state must still obtain preclearance for any election change in state law. ${ }^{108}$ While academics have argued that the Lopez decision essentially "settled" the federalism issue, they emphasize that "there is considerable tension below the surface" of the debate. ${ }^{109}$ This tension was illustrated in a recent concurring opinion written in a separate case by a federal court judge in Alabama. Acknowledging that precedent dictated Section 5's constitutionality, Judge DeMent's opinion grumbled that preclearance requires "states to grovel at the feet of the Attorney General or the District Court for the District of Columbia." 110

There are two primary reasons why such "groveling" is a valid and even necessary requirement to impose on the covered jurisdictions and why, accordingly, civil rights advocates should attempt to invalidate these federalism concerns. First and foremost, as the Court has noted, ${ }^{111}$ Section 5

105. This section will assume that the Fourteenth and Fifteenth Amendments permit such an intrusion. For more on that debate, see discussion of the constitutionality of Section 5 supra part II.A. accompanying notes 71-95.

106. See Rodriguez, supra note 75 , at 803 ("The oft-invoked image is of a local official traveling, hat in hand, to Washington, D.C., to ask if it would be okay to move a polling place from point A to point B back in his or her home town.").

107. 525 U.S. 266 (1999).

108. Id. at 269 .

109. Winke, supra note 92, at 87.

110. Ward v. Alabama, 31 F. Supp. 2d 968, 979 (M.D. Ala. 1998) (DeMent, J., concurring).

111. See Katzenbach v. Morgan, 384 U.S. 641 (1966). 
coverage is narrowly tailored to apply only to jurisdictions with the most egregious record of discriminatory election practices. ${ }^{12}$ An analysis of instances where the DOJ has denied preclearance shows a strong correlation between those denials and a history of previous discrimination. ${ }^{13}$ Second, the bailout provision in the VRA allows covered jurisdictions that have been "discrimination-free" for a number of years to be removed from preclearance requirements. ${ }^{14}$ This allowance ensures that Section 5 remains continually focused on areas where such oversight has proved necessary to prevent or respond to voting rights abuses. ${ }^{115}$

\section{The Inconsistency Issue}

In addition to the constitutional and states' rights concerns over Section 5 , many critics have voiced concern about inconsistencies that haunt the enforcement of Section 5 and Section 2 of the VRA. In particular, scholars note that some plans or election changes that would violate Section 2 might still pass preclearance under Section 5, or changes that are not precleared by the federal government might pass Section 2 scrutiny. This confusion leads some, including Justice Kennedy, ${ }^{116}$ to argue that Section 5 should be allowed to expire, permitting Section 2 to be the sole criterion under which the election laws are evaluated. ${ }^{117}$

Further complicating these inconsistencies is the question of whether Section 5's retrogression standard permits unconstitutional districting

112. Indeed, some of the political leaders who committed the worst abuses still play influential roles in the governments of covered jurisdictions. Joe Smitherman, Mayor of Selma, Alabama when voting rights abuses spawned a violent march from Selma to Montgomery in 1965, remained Mayor of Selma until 2000. Zondra Hughes, Selma's First Black Mayor, EBOny, Dec. 2000, at 66.

113. See Rodriguez, supra note 75, at 803-04 (noting that "most abuses recorded by the DOJ have occurred in precisely those jurisdictions with the worst history of abuse. If an analysis were to focus on just Alabama, Georgia, Louisiana, Missouri, North and South Carolina, Texas, and Virginia, these eight states (out of the sixteen covered either in part or in whole) would account for 563 out of 599 (almost 94\%) of all objections entered by the DOJ to block proposed changes.").

114. See discussion supra part I.A. accompanying note 41 on the 1982 enactment of the bailout provision

115. See Rodriguez, supra note 75 , at 804 (noting that, currently, "each state that is covered either in part or in whole has had at least one objection entered against it since the last reauthorization"); $i d$. at 805 ("There have been relatively few successful bailout suits, however, and this low rate of bailout success indicates that there have been ongoing violations and thus a continued need for Section 5.").

116. See Georgia v. Ashcroft, 123 S. Ct. 2498, 2517 (2003) (Kennedy, J., concurring).

117. See supra Introduction for a discussion of the two standards, an examination of the presence of vote dilution under Section 2 and the retrogression standard of Section 5. 
schemes. ${ }^{118}$ The Supreme Court's opinion in Shaw v. Reno ${ }^{119}$ explicitly barred state and local governments from using race as a predominant factor in their districting efforts. ${ }^{120}$ Many jurisdictions, however, find that they must use race as a consideration if their redistricting plans are to comply with Section 5. As a result, critics argue, Section 5 pushes covered jurisdictions to take race into consideration when changing election procedures or redistricting, while the Equal Protection Clause prohibits race from being a predominant factor. $^{121}$

A great deal of confusion has been created by these perceived conflicts. ${ }^{122}$ As leading voting rights scholar Pamela Karlan summarizes, "[s]tates now find themselves walking a tightrope: if they draw majority-black districts they face lawsuits under the equal protection clause; if they do not, they face both objections under Section 5 of the Voting Rights Act and lawsuits under Section 2." ${ }^{23}$ Other scholars, however, have argued that this is not the case, and that compliance with Section 5 in particular does not require that race be considered, arguing in opposition that "Section 5 forbids covered jurisdictions to consider race in redistricting decisions even when in compliance with the non-retrogression principle.", 24

118. Errickson, supra note 36, at 2059.

[T] he problem that a state faces in redrawing its congressional districts is this: in order to avoid suits alleging equal protection violations, the state must prove that race was not a predominant factor in sketching district boundaries. For a state to overcome the preclearance hurdle, however, it has to prove that its new plan complies with the section 5 non-retrogression principle, which almost always requires race-conscious districting. Id.

119. 509 U.S. 630 (1993).

120. Id. at 657-58. Justice O'Connor expressly declined to address the question of "whether the intentional creation of majority-minority districts, without more, always gives rise to an equal protection claim." Id. at 649.

121. Errickson, supra note 36, at 2059. The Court's recent opinion in Georgia v. Ashcroft, however, gives jurisdictions more leeway in creating and preserving majority minority districts. See supra text accompanying notes 58-67. There is nothing in the opinion, however, indicating a clear departure from requiring jurisdictions covered by Section 5 to use race as a consideration when devising their apportionment plans.

122. See David M. Guinn et al., Redistricting in 2001 and Beyond: Navigating the Narrow Channel Between the Equal Protection Clause and the Voting Rights Act, 51 BAYLOR L. REV. 225, 227-28 (1999) (noting that "governments must determine how to construct redistricting plans that accommodate these competing federal requirements").

123. Pamela S. Karlan, Still Hazy After All These Years: Voting Rights in the Post-Shaw Era, 26 Cumb. L. Rev. 287, 289 (1996).

124. James F. Blumstein, Racial Gerrymandering and Vote Dilution: Shaw v. Reno in Doctrinal Context, 26 Rutgers L.J. 517, 563 (1995). 
This contention leads some to argue the protections against vote dilution in the Equal Protection Clause and Section 2 are sufficient for protecting minority electoral strength and participation. ${ }^{125}$ In essence, supporters of this argument believe that Section 2 vote dilution claims are sufficient at reaching discriminatory election laws and procedures. Such a viewpoint, of course, ignores the idea that Section 5 and Section 2 are designed to reach two different types of discriminatory election systems; Section 5 looks at plans as compared with the previous status of minority voters in the area, while Section 2 looks at plans from an objective standpoint. ${ }^{126}$

There are a few solutions that would allow Section 5 to be renewed while resolving some of the inconsistency concerns. Some scholars have argued, for example, that the retrogression standard of Section 5 should be replaced with the vote dilution standard of Section $2 .{ }^{127}$ This would mean that, under Section 5, only election changes that would result or are intended to result in vote dilution would be denied preclearance. ${ }^{128}$ Others have proposed altering the constitutionality test established in Shaw v. Reno, allowing a "presumption of constitutionality in favor of districts drawn from precincts or tracts where the supposedly favored racial group does not have a controlling electoral majority." 129 Another idea, aimed specifically at resolving the redistricting confusion, involves requiring Congress to articulate, in legislation, an explicit list of traditional redistricting principles. ${ }^{130}$ Suggestions such as these should be part of the reauthorization debate or explored as potential compromises to put forth if the inconsistency issue becomes a major roadblock.

\section{The Symbolic Issue}

Lastly, and perhaps most importantly, arguments surrounding the expiration of Section 5 must acknowledge the overall symbolic significance

125. See Hiroshi Motomura, Preclearance Under Section Five of the Voting Rights Act, 61 N.C.L. REV. 189, 196 (1983) (arguing that the "constitutional law of vote dilution, rather than the retrogression test, offers a more reliable guide to the substantive principles that have developed under Section 5").

126. See Errickson, supra note 36, at 2069 ("Section 5 protects minority voters from the necessity of bringing suit against the state for enacting a more discriminatory districting plan than the one currently in use by blocking the proposed plan from ever taking effect. By contrast, section 2 provides protection against plans that are objectively, rather than comparatively, discriminatory.").

127. See, e.g., Benson, supra note 72; Heather K. Way, Note, A Shield or a Sword? Section 5 of the Voting Rights Act and the Argument for the Incorporation of Section 2, 74 TEX. L. REV. 1439 (1996).

128. See discussion on incorporation infra accompanying notes 226-32.

129. Hebert, supra note 61, at 463.

130. Guinn et al., supra note 122, at 264. 
of its protections. In light of the presidential voting debacle in Florida in 2000 and the problems faced by African-American voters in 2004, as well as the conclusions reached by various academics and practitioners regarding continued barriers to participation by minority voters, ${ }^{131}$ there will be great symbolic significance surrounding Congress's decision to renew one of the most important provisions of the VRA. ${ }^{132}$ Allowing Section 5 to expire would send a signal that Congress is no longer committed to protecting minority voters from continued efforts to dilute their electoral strength. Therefore, it is important that any effort geared towards pushing for reauthorization includes specific reference to the subtle but real symbol of the continued presence of Section 5 protections.

Various studies have linked an increase in minority participation, representation, and empowerment to the symbolic protections of Section $5 .{ }^{133}$ Lani Guinier, a scholar who was deeply involved with the 1982 reauthorization effort, has commented that "[p]rotecting the right to vote [through a strong VRA] furthers the goal of black political empowerment, meaning the opportunity to use the vote to mobilize support within the political process to overcome blacks' depressed and isolated economic and social status." 134 Any weakening of Section 5 would threaten such empowerment.

Other academics have emphasized that there continues to be a general importance of increasing and maintaining racial diversity among elected officials representing an increasingly diverse electorate, and cite Section 5 as critical to enabling that diversity. ${ }^{135}$ Subtle but important benefits of such diversity include a "greater stability in society due to an enhanced sense of

98.

131. See, e.g., Drawing Effective Minority Districts, supra note 66, at 1404-05; EDLEY, supra note

132. See, e.g., Rodriguez, supra note 75 , at 812 (referring to Section 5 as "a symbol of voting rights protections for the last four decades").

133. See generally Quiet Revolution in the South: The Impact of the Voting Rights Act, 1965-1990 (Chandler Davidson \& Bernard Grofman eds., 1994); see also Motomura, supra note 125, at 190 ("Of the Act's many provisions, section 5 has emerged as perhaps the most important for the continuing protection of minority voting rights."). (1991).

134. Lani Guinier, No Two Seats: The Quest for Political Equality, 77 VA. L. Rev. 1413, 1423

135. See, e.g., Steve Bickerstaff, Effects of the Voting Rights Act on Reapportionment and Hispanic Voting Strength in Texas, 6 TEX. HIsP. J.L. \& PoL'y 99, 122 (2001) (noting that both the United States and Texas "have become stronger both politically and economically as a result of the application of the [VRA] to increase the representation of racial and ethnic minority groups in governments nationwide"). 
shared interests and inclusion" and "improved economic efficiency because fewer resources are lost to internal unrest and distrust."136

Section 5 is a message that the federal government sends to minority voters, in jurisdictions that have been hostile to their interests and rights, promising that those localities will never again be permitted to enact barriers that hinder the electoral strength of their electorate. It is important and vital that efforts to renew Section 5 emphasize the unspoken message of abandonment that Congress would send to both minority voters and the electorate as a whole if they choose not to reauthorize the provision. ${ }^{137}$

\section{A Clarified, Renewed Section 5}

While there are real and deep debates over whether to reauthorize Section 5 , the resolution of that issue is not the end of the conundrum. Even among civil rights and voting rights advocates and academics who agree that Section 5 must be renewed, there is extensive debate over the form that the renewed version should take. These issues are touched upon briefly in the previous section, but many suggested changes have gone beyond mere suggestions at corrective compromises, at one end arguing for the narrowing of some of the section's provisions ${ }^{138}$ and at the other end arguing for the expansion of the section's protections to adjust to demographic changes. ${ }^{139}$

Across this spectrum, suggestions of amendments to Section 5 can be thematically understood as an effort to clarify various terms, currently undefined or defined through Supreme Court case law. The following

136. $I d$.

137. See Rodriguez, supra note 75 , at 825 ("[a]t a time when voter cynicism and apathy drives voter participation rates to new lows with each election and when there is a retrenchment of conservative politics that many perceive as anti-minority, there is a need for a symbolic and substantive commitment on the part of government to protecting the right to vote for people of color.").

138. Suggested in a letter from Bernard Grofman, Professor of Political Science, University of California, Irvine, to Barbara Amwine, Executive Director, Lawyers' Committee for Civil Rights Under Law (Mar. 24, 2004) (on file with author).

139. Rodriguez, supra note 75 , at 810 .

As minorities move into new communities in different parts of the country, there will almost certainly be friction not only between Whites and Latinas/os but also between established communities of racial minorities and the recently arrived minority group, who represents new electoral "competition." This competition and perception of a zero-sum game will increase the likelihood that established communities (White and non-White) may resort to finding ways to maintain their power and to prevent the newcomers from the full enjoyment of their voting rights. Section 5's original framework may need to be reconceptualized in this multiethnic context. 
discussion will focus on the terms that most need clarification, analyzing the contention around their current vague definitions and interpretations.

\section{A. The Redistricting Conundrum}

At the core of many debates surrounding preclearance is whether Section 5 should prohibit or protect certain types of districting changes. Terms like "majority-minority districts," "influence districts," and "coalition districts" are at the center of this debate, as well as questions regarding the effect of such districts on the turnout, electability, and the general representation of minority voters. Many of these disagreements, however, may be resolved by the mere clarification of the definitions of these three types of districts. Whether a district is deemed "majority-minority," "influence," or "coalition" is generally based on the percentage of the minority voting age population within that district, yet these terms have primarily been employed by academics while Congress and the courts remain silent on the specifics of the terms.

But even assuming the districting terms are officially clarified, a more contentious question remains as to whether the enforcement of Section 5 should involve the prohibition or protection of certain types of districts. This feeds into a third, core issue: the effect certain districts have on direct representation of minority voters (through the election of their "candidate of choice" or "descriptive candidate"), and their broader, substantive representation (through the election of candidates who they may not have chosen but who effectively represent their policy interests once elected). This section will attempt to look at each of these issues in turn.

\section{Defining Majority-Minority, Influence, and Coalition Districts}

Central to the confusion over the three district definitions are the various views on what specific percentages of minority voters are required to create a "majority-minority" district, where voters of color are virtually guaranteed the election of their candidate of choice. ${ }^{140}$ Scholars, courts, the Department of Justice (DOJ), and practitioners have all differed over what precise percentages are required to create such a district, resulting in great confusion over whether a majority-minority district has "packed" too many minority

140. The phrase "ability to elect candidates of choice" typically refers to the power of minority voters, as a bloc, to elect candidates who will effectively represent their interests. See, e.g., Thornburg v. Gingles, 478 U.S. 30, 46 (1986). 
voters into one district and "bleached" other areas, ${ }^{141}$ and what is the precise "tipping point," or number of minority voters needed to ensure the election of a minority candidate of choice. A further complication involves questions over what the "majority" percentage should reflect-either the number of voters from one single race or ethnic group, or an aggregate calculation of all the voters of color in a district. ${ }^{142}$

In 2001, the redistricting commission for the State of Arizona encountered the effects of this confusion head-on; they defined a majorityminority district as one in which $45 \%$ or more of the total population were members of any racial minority, while the DOJ considered districts drawn so that at least $55 \%$ of the voting age population were members of any racial minority. ${ }^{143}$ The contention specifically centered on a difference of opinion as to what percentage of minorities was sufficient to elect the minority candidate of choice. ${ }^{144}$ In the eyes of the Arizona Redistricting Commission, its new apportionment plan created ten majority-minority districts, while in the DOJ's eyes, only five were created. Under the DOJ's definition, Arizona's original "benchmark" plan, in place prior to the redistricting, had seven majority-minority districts. Thus, despite the fact that the Arizona Redistricting Commission thought it was actually increasing the number of majority-minority districts in the state, under the DOJ's interpretation it had actually reduced the number of majority-minority districts. ${ }^{145}$ Accordingly, the plan was found to be retrogressive and denied preclearance.

This example could be written off as a case of the Arizona Redistricting Commission having a false conception of a majority-minority district, or of the

141. This "bleaching" principle is based on the theory that the creation of majority-minority districts causes surrounding districts to lose so many minority voters that those districts become super-majority white districts. See, e.g., Pamela Karlan, Loss and Redemption: Voting Rights at the Turn of a Century, 50 VAND. L. ReV. 291, 293 (1997).

142. I.e., "Percentage of Black voting age population" (BVAP) versus "Percentage of Black and Latino voting age population" (BLVAP).

143. See Rhonda L. Barnes, Redistricting in Arizona under the Proposition 106 Provisions: Retrogression, Representation and Regret, 35 ARIZ. ST. L.J. 575, 583-86 (2003), for more details of this dispute.

144. In this case, the percentage of minorities indicated all voters of color in a jurisdiction.

145. Barnes, supra note 143, at 584-85 ("[F]our districts to which the D.O.J. objected were in fact majority-minority districts. This seems to indicate that the D.O.J. does not consider a majority-minority population to be sufficient to protect the minority groups' ability to elect a candidate of their choice. The D.O.J. objection letter requires the electors in the contested districts to have the power to elect the 'candidate of their choice' in order to avoid the determination of a retrogressive effect.... [In the opinion of the DOJ] the majority was not 'enough,' and thus the I.R.C. had to pack more minority voters into those four districts, leaving the remaining districts with a disproportionately small number of minority (and often Democrat) voters."). 
DOJ doing a poor job in educating covered jurisdictions of the requirements of preclearance. In fact, some commentators have noted that the DOJ's definition is quite nebulous. ${ }^{146}$ Regardless of which conclusion one reaches, however, Arizona's difficulties highlight the need for better districting definitions.

The confusion over the proper definition of a "majority-minority district" has also spilled into academia. ${ }^{147}$ Like the Arizona example, these debates have primarily involved questions over what percentages of minority voters are required to ensure that the minority candidate of choice is virtually certain to be elected. But, the academic debates also illustrate the importance of resolving the related and similarly vital question: how the percentages of minority voters should be calculated - as a collective group of minority voters or as individual racial or ethnic groups. For example, some consider districts to be majority-minority where Black and Hispanic populations combined comprise $55 \%$ of a district's electorate. ${ }^{148}$ Others would consider that district not to be a majority-minority district, since neither the Black population on its own, nor the Hispanic population on its own, comprise a majority of the electorate. ${ }^{149}$ In one of the most public academic debates over this issue, one study examined districts where the Black electorate was above $50 \%$ and concluded that majority-minority districts were no longer necessary to elect minority candidates of choice because Black candidates of choice had been elected in districts where the Black populations were under 50\%. ${ }^{150}$ Three years later, however, another academic challenged the results by noting that all of the districts in the previous study that had elected Black candidates of

146. See Katharine Inglis Butler, What Minority Populations are Sufficient to Afford Minorities a Realistic Chance to Elect Candidates of Choice?: A Functional Analysis of Potential Voting Rights Act Liability May Demonstrate That the Intentional Creation of Black Remedial Districts Cannot be Justified, 79 N.C. L. REv. 1431, 1464 (2001) ("Obviously a critical question for covered jurisdictions is what constitutes a [majority] 'black district' for purposes of measuring retrogression? ... As a practical matter, the important definition is the one the Justice Department - the entity to which a covered jurisdiction must submit its redistricting plan to obtain administrative preclearance-employs. ... [I]n the arguable absence of a clear judicial definition of a minority district, the Department may be emboldened to select any plausible measure that will permit it to find retrogression.").

147. For a detailed overview of the debates between Grofman/Handley and Swain or Lublin and Epstein/O'Halloran on the definition of majority-minority districts, see Grofman et al., supra note 66, at 1390-93.

148. See, e.g., Charles Cameron et al., Do Majority-Minority Districts Maximize Substantive Black Representation in Congress?, 90 AM. PoL. SCI. Rev. 794 (1996).

149. See, e.g., David Lublin, Racial Redistricting and African American Representation: A Critique of Do Majority-Minority Districts Maximize Substantive Black Representation in Congress?, 93 Aм. PoL. SCI. Rev. 183 (1999).

150. See Cameron et al., supra note 148 , at 808 . 
choice had majority-minority populations when Black populations were combined with the Latino citizens in the district. ${ }^{151}$

This contention is closely related to the difficulties in defining influence and coalition districts. In general terms, these are districts where there are low percentages of minority populations but where, at least in theory, these populations are still large enough to have "influence" over the outcome of an election or to be able to form "coalitions" with other voters in order to exert influence. ${ }^{152}$

But even at this vague level, scholars and courts have differed over what precise terms describe either district. Professor Richard H. Pildes, a leading election law commentator, has referred to "coalition districts" as districts where minority voters have a 50-50, but less than certain, chance of electing their candidate of choice. ${ }^{153}$ The Supreme Court, however, has referred to this sort of district as an "influence" district. ${ }^{154}$ Lower courts have used the term "influence districts" to refer to districts in which minority voters wield so much influence that white officeholders and candidates must be attentive to the concerns of minority voters in order to win and remain in office. ${ }^{155}$

This issue was conflated in Georgia v. Ashcroft, where the Court's opinion appeared to use the two terms-coalition and influenceinterchangeably, even though academics have emphasized that they "are decidedly not the same." 156 Karlan notes, "[b]eing part of a winning coalition in which a sufficient number of white voters support a candidate sponsored by the black community may be quite different from having some less direct

151. See Lublin, supra note 149, at 183-84. Lublin's own research examined Congressional elections held between 1972 and 1994, and found that across the board, "African Americans have an 86\% chance of winning in districts that are $55 \%$ black that contain no Latinos" and that "the probability of victory drops quickly below this percentage unless the share of Latinos increases." Id. at 183. Further, between 1972 and 1994, "blacks won only 72 of 5,079 elections" held in districts where they were not a majority —and 54 of those victories were in districts where African Americans and Latinos together formed a majority. Id.

152. See, e.g., Georgia v. Ashcroft, 123 S. Ct. 2498, 2513 (2003). See generally Luke P. McLaughlin, Note, Gingles in Limbo: Coalitional Districts, Party Primaries and Manageable Vote Dilution Claims, 80 N.Y.U. L. Rev. 312 (2005).

153. Richard H. Pildes, Is Voting-Rights Law Now at War with Itself? Social Science and Voting Rights in the 2000s, 80 N.C. L. REv. 1517, 1522 (2002) (coining and defining the term "coalitional districts") [hereinafter Pildes, Is Voting-Rights Law Now at War].

154. See Voinovich v. Quilter, 507 U.S. 146, 154 (1993).

155. See, e.g., Rural W. Tenn. African-Am. Affairs Councilv. McWherter, 877 F. Supp. 1096, 1098 (W.D. Tenn. 1995) (three-judge panel) (noting that "influence districts" would "most likely [be] represented by whites").

156. Karlan, supra note 63 , at 32 . 
effect on election outcomes." 157 Karlan offers the case of Alabama Senator Richard Shelby as an example, referring to the state of Alabama as a "natural influence district." 158 Though he was not a candidate of choice of Black Alabama voters, the support of Black voters was crucial to his winning election to the U.S. Senate in 1986, and re-election in 1992. But, Karlan notes, Shelby never represented the interests of Black voters in his state, nor did Black voters have "much real influence over Shelby." 159

The Court's recent endorsement of influence and coalition districts in Georgia v. Ashcroft marks a need for more comprehensive definitions of all three types. ${ }^{160}$ And whether this definition is crafted by Congress or the courts, various factors need to be considered. Most importantly, the degree of polarized voting in a district greatly affects the ability of minority voters to exert influence and build cross-racial coalitions, so it is also important that any working definition of these districts considers that issue. ${ }^{161}$ Other contextspecific factors, such as racial disparities in registration or turnout rates, have a similar impact on the meaning of minority voters' influence and ability to build coalitions. As Congress works through the reauthorization of Section 5 , it should consider whether to clarify these districting terms with ranges of percentages and other factors that, combined, can best predict which types of candidates will be elected and how responsive they will be to minority voters.

157. Id.

158. According to 1980 Census data, the black population in Alabama in the 1980 s was roughly $25 \%$ of the entire state population. U.S. Census Bureau, Table 15. Alabama-Race and Hispanic Origin: 1800 to 1990, available at $\mathrm{http}: / / \mathrm{www} . c e n s u s . g o v /$ population/documentation/twps0056/tab15.pdf.

159. Karlan, supra note 63 , at 32.

160. This determination is closely linked to the above discussion of which racial proportions best achieve the goals of majority-minority districts. In some cases, districts where the population is, for example, $20 \%$ Hispanic and 35\% Black, would be majority-minority, but in others they would be termed "influence" or "coalition" districts since the individual racial minority populations are both under $50 \%$.

161. Georgia v. Ashcroft, 123 S. Ct. at 2498, 2518 (Souter, J., dissenting).

Before a State shifts from majority-minority to coalition districts, however, the State bears the burden of proving that nonminority voters will reliably vote along with the minority, . . . It must show not merely that minority voters in new districts may have some influence, but that minority voters will have effective influence translatable into probable election results comparable to what they enjoyed under the existing district scheme. And to demonstrate this, a State must do more than produce reports of minority voting age percentages; it must show that the probable voting behavior of nonminority voters will make coalitions with minorities a real prospect.

Id. (internal citations omitted). 


\section{Beyond Clarification: Should Section 5 Protect Majority-Minority} Districts?

The above section touches on some of the complications encountered by courts, advocates, and academics arguing over how to define various kinds of districts in a way that accurately reflects the district's effect on minority voting strength. But beyond the discussion on determining specific definitions for majority-minority, influence, and coalition districts, ${ }^{162}$ lies an even more contentious debate over whether Section 5 should protect or encourage the preservation of majority-minority districts at the expense of the other two.

For example, some commentators argue that Section 5's historical protection of majority-minority districts in covered jurisdictions has led to a correlative increase in Republican representation in the surrounding "bleached" districts. ${ }^{163}$ In this vein, they argue that there is a trade-off involved between the direct representation of minority voters and the broader substantive representation of their interests. ${ }^{164}$ Whether there is indeed a "trade-off," however, is far from certain. This section will provide an overview of the empirical evidence surrounding the debate as a way of illustrating the intensity of disagreement over whether Section 5 preclearance should protect majority-minority districts.

The purpose of majority-minority districts is to enable historically disenfranchised and geographically concentrated racial groups to elect their candidates of "choice." 165 The particular need to concentrate minority voters

162. For clarity's sake, the remainder of this paper will use the term "majority-minority district" in general terms to refer to districts where minority voters are at least $55 \%$ of the voting-age population, with white voters comprising the other $45 \%$. Similarly "influence district" will refer to districts where minority voters comprise $35-50 \%$ of the voting-age population, with white voters comprising the balance, and "coalition" district will refer to districts where minority voters are $25-35 \%$ of the voting-age population, with white voters making up the other $65-75 \%$. These definitions are based on those now generally employed by the U.S. Supreme Court. See Georgia v. Ashcroft, 123 S. Ct. 2498 (2003).

163. See, e.g., Carol M. Swain, Black Faces, Black Interests: The Representation of AFRICAN AMERICANS IN CONG RESS (1993) (suggesting that minority districts actually may hurt the careers of individual minority politicians because, although they may win seats in Congress, they fail to gather the broad interracial support required to reach higher office).

164. Pildes, Is Voting-Rights Law Now at War, supra note 153, at 1562.

165. While the definition articulated supra note 140 will be used for the purposes of this paper, the phrase "candidate of choice" is yet another uncertain term in voting rights parlance. Some commentators have suggested ways to clarify this term. See David Epstein \& Sharyn O'Halloran, Measuring the Electoral and Policy Impact of Majority-Minority Voting Districts, 43 AM. Pol. SCI. Rev. 367 (1999) (proposing that a candidate be deemed a "candidate of choice" if (1) in no election was a significant negative correlation observed between black voter turnout and votes for that candidate; AND (2) the candidate must be either a minority candidate or elected from a majority-minority district). 
into districts is based on the presence of racially polarized voting in various jurisdictions, particularly those areas covered by Section 5 of the Voting Rights Act. ${ }^{166}$ Majority-minority districts were developed in response to these voting patterns as a means of increasing and protecting the political power and representation of minority voters. ${ }^{167}$

Most voting rights and election law commentators generally agree that past degrees of racially polarized voting made majority-minority districts necessary to ensure that minority voters had an equal opportunity to elect candidates of their choice. ${ }^{168}$ Richard Pildes, now a vocal opponent of majority-minority districts, wrote that when the 1990 redistricting efforts began:

In state and local elections in Georgia during the 1980s, an average of $86 \%$ of White voters voted for the White opponent of a Black candidate. In Mississippi, no Blacks were elected to city councils in districts with less than a $50 \%$ Black population; indeed, until Black populations in these districts reached at least $65 \%$, Blacks remained dramatically underrepresented. ${ }^{169}$

166. When voting is racially polarized, as defined by the U.S. Supreme Court, "the white majority votes sufficiently as a bloc to enable it - in the absence of special circumstances, such as the minority candidate running unopposed . . usually to defeat the minority's preferred candidate." Thornburg v. Gingles, 478 U.S. 30, 51 (1986).

167. Many scholars have noted both the theoretical and practical reasons for such protection. See, e.g., Cameron et al., supra note 148, at 809 ("The appropriate representation of minorities was central to the debates at the founding of the American Republic. The Federalist $10 \ldots$ warned against the dangers of majority tyranny and suggested ways to design institutions to offset this possibility."); Penda Hair \& Pam Karlan, Redistricting for Inclusive Democracy: A Survey of the Voting Rights Landscape and Strategies for Post-2000 Redistricting, in A Report from Advancement Project 1 (June 2000) ("Citizens who lack even a chance to elect the candidates of their choice may rationally opt out not only from the individual act of voting, but also from the broader process of civic participation.").

168. See, e.g., Drawing Effective Minority Districts, supra note 66, at 1390-91 ("In the South during the 1970s and 1980s, data . . provided compelling evidence of racially polarized voting in numerous jurisdictions. Further, because a higher proportion of blacks than whites were not of voting age, and because black levels of political participation were less than those of whites, . . districts with $65 \%$ black population were needed before African-American candidates could win [an election]."); Bernard Grofman \& Lisa Handley, The Impact of the Voting Rights Act on Black Representation in Southern State Legislatures, in LEGIS. STUD. Q. 111 (1991) (noting that the increase of black legislators in state legislatures in the South was a result of majority-minority districts).

169. Richard H. Pildes, The Politics of Race, 108 HARv. L. Rev. 1359, 1368-69 (1995) (reviewing Quiet Revolution in the South: The Impact of the Voting Rights Act, 1965-1990 (Bernard Grofman \& Chandler Davidson eds., 1994)); see also Pildes, Is Voting-Rights Law Now at War, supra note 153, at 1525 ("From 1972 to 1992 , the probability of a majority-white congressional district electing a black representative remained at [a] negligible level regardless of a district's median family income, its percentage of high school graduates, the region of the country, or the proportion of residents who were urban, elderly, foreign born, or residents of the relevant state for more than five years . . . every majority black congressional district in the South (out of four) elected a black candidate to office; only one 
Dissension grew in the early 1990s, however, as some commentators began to question the long-term benefits of majority-minority districts ${ }^{170}$ and whether the degree of racially polarized voting was decreasing in such a way as to make the need for "safe" electoral districts irrelevant. ${ }^{171}$ In addition, scholars on both sides began to disavow the above-mentioned benchmark of $65 \%$ minority voting-age population as being necessary for minority voters to elect their candidates of choice. ${ }^{172}$ This opened the door for proponents of influence and coalition districts to begin arguing that concentrating high percentages of minority voters in one district diluted their overall voting strength in the state by "packing" them into single districts. ${ }^{173}$

The extension of this argument has partisan implications, since minority voters are traditional supporters of the Democratic Party, and their interests are typically best served by the Democratic Party platform. ${ }^{174}$ Thus, some argue that when minority voters are concentrated into majority-minority districts, the support for Democratic candidates in surrounding districts is diminished. Those districts are then "bleached," as the number of white Republican voters correspondingly increases. As a result, notes one commentator, "while majority-minority districting has succeeded in sending

nonmajority black district in the South (out of 112) elected a black candidate.").

170. See, e.g., Jeffrey P. Lisenby, Racial Politics Alive and Well in Alabama: The Impact of Recent Voting Rights Decisions on Alabama's Electoral Districts, 46 ALA. L. REv. 641, 658 (1995) ("[T]he creation of majority-minority districts, which openly separate citizens on the basis of race, contributes to racial divisiveness, exacerbates racial tensions, and diminishes our chances of achieving a true 'color blind' society.").

171. See, e.g., Charles S. Bullock, III \& Richard E. Dunn, The Demise of Racial Districting and the Future of Black Representation, 48 EMORY L.J. 1209, 1213 (1999) ("In general, we find that these [black congressional] incumbents attract about one-third of the white general election vote, a result that is in line with levels of white support for white Democratic candidates for other federal offices in the South.").

172. Pildes, Is Voting-Rights Law Now at War, supra note 153, at 1527 ("[B]y 1990, the 65\% rule was considered exceptional."). Note that in the same article, however, Pildes also admitted that "districts with $55 \%$ black populations were generally sufficient to enable black voters to defeat racial bloc voting, while districts less than $45 \%$ black almost never elected black representatives." Id.

173. See, e.g., Cameron et al., supra note 148, at 809 (arguing that requiring a majority of $65 \%$ or more "dilutes rather than increases overall minority voting strength").

174. The extent of this partisan alliance is highly debatable. See generally Maxine Burkett, Strategic Voting and African-Americans: True Vote, True Representation, True Power for the Black Community, 8 Mich. J. RACE \& L. 425 (2003) (questioning the historical alliance between Black voters and the Democratic Party). However, it remains a political reality, as, for example, $90 \%$ of African American voters voted for Vice President Al Gore in the presidential election of 2000. Brian P. Marron, Book Note, 3 Conn. Pub. Int. L.J. 195, 231 (2003) (reviewing Jamin B. Raskin, Overruling Democracy: The Supreme Court v. The American People (2003) (citing U.S. Census Bureau, Statistical Abstract of the United States 2002, at 235, available at $\mathrm{http}: / /$ www.census.gov/prod/2003pubs/02statab/election.pdf)). 
record numbers of minorities into Congress, it also has contributed to the success of Republican candidates who often oppose most of the legislative programs that minority groups support." ${ }^{175}$

This "tradeoff" - an increase in the direct representation of minority voters at the expense of a decrease in the success of Democratic candidates in surrounding areas - is believed by some to have resulted in the Republican takeover of the House of Representatives in 1994. ${ }^{176}$ Specifically, in the redistricting efforts following the 1990 census, thirteen new majority-minority districts were created in the South. ${ }^{177}$ In 1992, nine Congressional districts replaced a Democrat with a Republican representative, followed by sixteen others in $1994 .{ }^{178}$

This has led some commentators to even suggest collusion between minority representatives and Republican leaders to produce more majorityminority districts at the expense of Democratic districts. ${ }^{179}$ Leading scholars, however, have debunked this theory. Voting rights expert Bernard Grofman ${ }^{180}$ cites two examples of Section 5 enforcement that indicate that the Department's motivation is to enforce the Act, regardless of its effect on Republicans. ${ }^{181}$ Specifically, two apportionment plans that created majority-

175. Lisenby, supra note 170, at 657 . See also Hench, supra note 37, at 751 ("While creating [majority-minority] districts guarantees a voice for an otherwise excluded community, it may also have a 'ghetto' effect ... guaranteeing that the remaining white districts will dominate the resulting elected body.").

176. Jerelyn Eddings, An Old War, a New Fight: Can Gerrymandering by Race Be Right?, U.S. News \& WoRld ReP., Sept. 26, 1994, at 53 (arguing that the increase of majority-black congressional districts in the South prior to the 1994 Congressional elections resulted in the number of Republicans elected to the House of Representatives from those districts growing from 39 to 48, while the membership in the Black Caucus also grew from 26 to 39).

177. Drawing Effective Minority Districts, supra note 66, at 1394.

178. See, e.g., Kimball Brace et al., Does Redistricting Aimed to Help Blacks Necessarily Help Republicans?, 49 J. Politics 169-85 (1987) (finding a positive and significant correlation between the number of majority-minority seats created in proposed South Carolina redistricting plans and the expected number of Republicans elected).

179. See generally Charles S. Bullock, III, Winners and Losers in the Latest Round of Redistricting, 44 EmoRy L.J. 943 (1995), for a description of how Janet Reno's Department of Justice enforced Section 5 preclearance in a way that encouraged the increase in majority-minority districts in covered jurisdictions.

180. Grofman is a leading expert witness for civil rights organizations in voting rights cases.

181. See Bernard Grofman, Would Vince Lombardi Have Been Right If He Had Said: "When it Comes to Redistricting, Race Isn't Everything, It's the Only Thing"?, 14 CARDozo L. REv. 1237, 1256 ("The view that Republicans are seeking to use the Voting Rights Act for partisan gain - a view that is accurate - must not be confused with the much stronger claim that the Republicans have actually been able to use the Voting Rights Act in that way. In particular, the assertion that the 1990s has seen partisan manipulation of the DOJ's preclearance and litigation decisions on behalf of the Republican party is largely unsupported."). 
minority districts were attacked by Republican plaintiffs in the early 1990s, but were still precleared by the DOJ. ${ }^{182}$ Further, in 1993, seven Republican Congressmen co-sponsored a bill to bar states from creating a district "with the intent to assure that a majority of the voters in that district are people of a particular race or color or language minority." 183

Collusion or not, the correlation of an increase in majority-minority districts in the South and an increase in the election of Republicans to the House of Representatives has led many to argue that there is a causal connection between the two. ${ }^{184}$ One commentator claimed that the creation of majority-black districts triggered "the larger collapse of the Democratic Party in the South," providing the Republican party "with the power to dominate national politics and dictate national policy." 185

A result of this blame-game, of course, is that minority voters are used as scapegoats for a phenomenon that was, in part, caused by a failure of the Democratic Party to maintain support in areas where they once had a stronghold. ${ }^{186}$ Fortunately, advocates have questioned this causation principal as greatly simplifying a complex set of factors that come into play in any

182. Pope v. Blue, 809 F. Supp. 392 (W.D.N.C. 1992) (attempting to block the implementation of North Carolina's 1990 congressional districting plan), aff'd, 506 U.S. 810 (1992); Republican Party of Va. v. Wilder, 774 F. Supp. 400 (W.D. Va. 1991) (challenging a Virginia apportionment plan as a racial gerrymander).

183. David Dahl, Republicans Work to Ban Districts Based on Race, St. Petersburg Times (Florida), Aug. 15, 1993, at 1A (stating that H.R. 2862, which was introduced in the U.S. House of Representatives by several Republican lawmakers, would prohibit racial gerrymandering).

184. See, e.g., Grofman \& Handley, supra note 44, at n.184 (citing an unpublished study by David Lublin). Lublin concludes that "the creation of new majority-minority districts assured that the Republicans won solid control of the House in 1994." Id. His study focused on seats decided by relatively small margins which lost substantial Black population in the 1990 redistricting efforts, and which shifted to the Republicans by 1994. In particular, he noted "that many of these seats could have remained in Democratic hands if the black population in these districts had been held at their previous levels." Id.

185. Michael Kelly, Segregation Anxiety, The New Yorker, Nov. 20, 1995, at 46, 48.

186. Various voting rights advocates have accused other academics of playing the "blame-game." See Selwyn Carter, African-American Voting Rights: An Historical Struggle, 44 EmORy L.J. 859, 859 (1995) ("In the months since the 1994 election, numerous commentators have blamed redistricting — specifically, the creation of 'majority-minority' districts - for the Republican takeover of Congress. This inaccurate scapegoating of minority voters for Democratic losses is not only wrong, it perniciously undermines support for the Voting Rights Act and the minority representation it has produced."). Others have noted that, with skilled redistricting experts, any perceived tradeoff can be eliminated. See Brace et al., supra note 178, at 183 ("[I]t is sometimes possible . . . to create new black Democratic districts while holding constant ... the total number of districts held by Democrats of either race. Thus, either because of skillful gerrymandering or because of overwhelming one-party dominance, the concentration of black voting strength in black majority seats may not affect the number of Republican majority seats.”). 
election. ${ }^{187}$ Others have noted that the 1994 gains by Republicans in the South have been greatly overstated. ${ }^{188}$

Additionally, two empirical studies conducted after the 1994 elections found that the growth of majority-minority districts between 1990 and 1994 did not have any role in the increase of Republican representatives in the South. Allan Lichtman, a professor of history at American University who frequently testifies as an expert witness in Voting Rights Act litigation, attributed any GOP gains to their success nationwide: "Democrats actually fared a bit better in the [eight Southern] states with new black districts ${ }^{189}$ than in the 41 states with no such districts." ${ }^{190}$ Lichtman further submits that "even if the Democrats had retained every one of the House seats lost in the nine states that had new majority black districts - in complete opposition to the nationwide Republican surge - the Republicans still would have gained control of the House in 1994."'191

A report published by the NAACP Legal Defense and Education Fund ("LDF") documented similar findings. Their report examined "six districts lost by Democrats in 1994 in Mississippi, Georgia and North Carolina and concludes that 'the [VRA] helped save Democratic seats in Mississippi and Georgia, as well as in other states." 192 Evidence in the LDF report also indicated that if the minority population in northern Mississippi had not been concentrated into one majority-minority district but instead spread between two Democratic districts, the Democratic Party would have likely lost both districts. ${ }^{193}$ Reviewing the LDF study, academics have concluded that the "real explanation for the Republican Party takeover of Congress" was the

187. See Laughlin McDonald, The Counterrevolution in Minority Voting Rights, 65 Miss. L.J.271, 297 (1995) (noting a number of potential causes for the rise of the Republican party in the South, including "white racial backlash, migration patterns, generational turnover, ideology, or some other cause or combination of causes").

188. See David A. Bositis, The Joint Ctr. for Pol. \& Econ. Studies, African-Americans \& THE 1994 MIDTERMS: WHAT HAPPENED? 17 (1995) (stating that "the creation of majority-minority districts per se cost the Democrats comparatively few seats in the south, say 10 (of 125)"); see also Kevin Hill, Does the Creation of Majority Black Districts Aid Republicans? An Analysis of the 1994 Congressional Elections in Eight Southern States, 57 J. PoL. 384, 386 (1995) (concluding that majority-minority districts in the South "cost the Democratic party about six seats in the 1994 Congressional Elections.").

189. Alabama, Florida, Georgia, Louisiana, Maryland, North Carolina, Texas and Virginia.

190. Allan J. Lichtman, Quotas Aren't the Issue, N.Y. Times, Dec. 7, 1994, at A23.

191. $I d$.

192. Carter, supra note 186, at 862 (citing NAACP Legal Defense And EduCA Tional Fund, The Effect of Section 2 of The Voting Rights Act on The 1994 Congressional Elections, Executive Summary (1994)).

193. $I d$. 
simple result of the fact that "the Republicans organized and got out their vote." $" 194$

The conclusion of these two studies - that Republican gains in the South were the result of a nationwide movement to support the GOP-has been criticized by other studies and commentators. ${ }^{195}$ Other studies have presented evidence corroborating these claims. ${ }^{196}$ And while it may be impossible to know for certain how the 1994 elections would have gone had majorityminority districts not been created, one thing is clear: without such districts there would have been little to no election of minority candidates of choice in the South. ${ }^{197}$

Underlying much of this debate are fundamental questions of what sorts of representation are most beneficial to minority voters. Indeed, the lamentability of any "trade-off"-whether or not it exists-rests on the assumption that Democrats best represent minority interests. It also leads to the question of whether that "substantive" representation is preferable to direct representation of minority voters via their candidates of choice.

The benefits of this direct representation are sometimes overlooked and worth emphasizing here. The presence of a minority voice in a legislature or governing body can have a significant impact beyond mere influence on policy decisions. The presence of that person may change the other members' perceptions about minority group members. Further, in smaller legislative bodies, other members will need to bargain with the minority member to gain her support on certain issues. And in larger bodies, like the U.S. House of Representatives, even a handful of elected minority candidates of choice can vote as a bloc and influence policy decisions - or at the very least will have a bully pulpit to use as a microphone to magnify their voices and the voices of their constituents.

Lastly, and perhaps most importantly, the positive effects of diversifying any governing body can extend beyond any direct effect on policy. It has been suggested, for example, that a minority candidate of choice may have a greater

194. Id.

195. See Grofman \& Handley, supra note 44, at 263 (noting that the LDF Report "neglected some of the negative consequences of creating majority-minority districts (for example, the incumbency advantage enjoyed by Republicans who won office in 1992 and sought reelection in 1994)").

196. Id. at 263 n.190 (citing an unpublished manuscript by John Petrocik \& Scott Desposato) (concluding that the creation of majority-minority districts would not "have defeated many Democratic incumbents if the election tide [in 1994] had been less hostile to the Democrats").

197. See, e.g., Grofman \& Handley, supra note 44, at 252 ("The dramatic increase in AfricanAmerican and Latino congressional representation has rested entirely on vastly improved access to the ballot combined with the creation of new majority-minority districts."). 
"psychological bond with constituents and will be more sympathetic to the needs of the minority group," making her a more effective representative of the interests of her constituents. ${ }^{198}$ Also crucial is the potential inspirational effect her presence may have on encouraging minority group members to participate in the political process, thus reducing group feelings of alienation. Apart from those positive effects on the electorate are the effects such diversity has on the governing body itself. As Judge Leon Higginbotham eloquently stated: "[a] Congress with members of all colors brings more American citizens into the political system ... it announces that government is for all Americans, increases the confidence of all American voters in the government, and thereby cultivates political participation of all Americans." 199

But other commentators have emphasized the need for broad substantive representation of minority interests and have warned that the election of minority legislators may not advance minority policy initiatives if the Republican Party continues to gain seats in the Congress and in state legislatures. ${ }^{200}$ An article by the Harvard Law Review noted that, in the years following the Republican takeover of 1994, "blacks across the country suffered a loss in influence, because the new black representatives found themselves in the minority party in the House, and thus less able to affect national policy. For example, no black representative has chaired a House committee since 1994." ${ }^{201}$

198. Elizabeth Bachman, Shooting Down the Phoenix: Shaw v. Reno and the Controversy Over Race-Conscious Districting, 22 Fordham URB. L.J. 153, 164 (1994).

199. A. Leon Higginbotham, Jr. et al., Shaw v. Reno: A Mirage of Good Intentions with Devastating Racial Consequences, 62 Fordham L. Rev. 1593, 1637-38 (1994).

200. Bullock, supra note 179, at 976-77 (warning that "[i]n the future ... black officeholders may find themselves isolated with virtually no support for their policy concerns from Republicans, and their white Democratic co-partisans moving rightward").

201. Note, The Future of Majority-Minority Districts in Light of Declining Racially Polarized Voting, 116 HARV. L. REv. 2208, 2228 \& n.105 (2003) [hereinafter The Future of Majority-Minority Districts] ("Congressman J.C. Watts, an Oklahoman who became the only black Republican in Congress when Representative Gary Franks of Connecticut lost his reelection bid in 1996, served as the House GOP Conference Chairman during the 106th and 107th Congresses. However, Watts chose not to run for reelection in 2002 despite this leadership position (one that made him the fourth-ranking Republican in the House"). 
This loss of influence has led some to challenge the presumptive connection between minority interests and Democratic policies. ${ }^{202}$ In particular, commentators have suggested that Republicans and AfricanAmericans find a range of issues around which to unite, noting that "[w]hile black legislators have often been liberal on a wide range of issues, there is evidence that the black electorate is conservative on some policies such as abortion. ... Black officeholders who are economic liberals but social conservatives will find allies on some issues in chambers with Republican majorities." 203

While a partisan realignment could address the issue, others have suggested the abandonment of the federal government's preservation of majority-minority districts in Section 5 jurisdictions as a solution. Instead, interpreting Section 5 to permit the creation of influence or coalition districts in lieu of majority-minority districts in covered jurisdictions could aid Democrats by enabling them to preserve partisan majorities in the influence districts.

This was the argument of the Georgia Democratic Party in Georgia v. Ashcroft. ${ }^{204}$ Its apportionment plan, which was upheld by the Court, opted to draw Democratic-majority influence districts where it could have drawn at least one majority-minority district. ${ }^{205}$ While the Democrats believed this would preserve their power in the Georgia State Legislature, they actually lost seats in the plan based on a massive grassroots campaign conducted by the Georgia State Republican Party, led by former Christian Coalition Executive Director Ralph Reed. ${ }^{206}$

In conjunction with that practical data, academics have also noted that while influence or coalition districts "may appear to be a solution" to any perceived "trade-off between descriptive and substantive representation," they are nowhere close to a panacea. ${ }^{207}$ "Even if lines are drawn to ensure the

202. See, e.g., Burkett, supra note 174, at 426 (encouraging Black voters to adopt a two-party strategy that courts the Democratic and Republican parties: "Black people can get what we want only if we present ourselves as true and shrewd consumers in the political marketplace ... Shrewd consumerism will force political parties to court our vote, then we could determine who is addressing 'our' issues most vigilantly. The question would be who has the best product rather than if there is any viable product at all.”).

203. Bullock, supra note 179, at 977.

204. 123 S. Ct. 2498 (2003).

205. Id. at 2500 .

206. See, e.g., Bill Torpy, GOP Chief Ralph Reed: Golden again; Did he lead the way or just ride the tide?, ATL. J. CONST., Nov. 10, 2002, at 2B.

207. See The Future of Majority-Minority Districts, supra note 201, at 2228. 
election of a Democratic candidate, the candidates who will be able to win in the district will probably be less receptive to the concerns of black voters than they would be in a majority-black district." 208

In light of this, it would seem that reinterpreting Section 5 to abandon its protection of majority-minority districts and allow the spread of influence and coalition districts in covered areas will not address the goal of preserving or bolstering minority electoral strength. Indeed, some experts have issued strong cautions against the replacement of majority-minority districts with influence districts, arguing that abandoning districts that have ensured the direct representation of minority voters will lead to a decimation of any real influence of minorities in governmental affairs. ${ }^{209}$

This issue is perhaps the most complicated dilemma facing advocates seeking to reauthorize Section 5. There are voting rights advocates who may only accept a reauthorized Section 5 that protects the creation of majorityminority districts and recognizes the importance of direct representation of minority voters. ${ }^{210}$ Others may agree that Section 5 remains relevant to voting rights law, but will only support the reauthorization in its current state postGeorgia v. Ashcroft. ${ }^{211}$ The resolution of this dilemma will be crucial to building consensus among advocates pushing for renewal, and research that may help resolve the tension should be at the top of any agenda for 2007.

\section{B. Clarifying the Retrogression Standard}

Closely linked to the debate over whether a renewed Section 5 should encourage the creation of majority-minority districts is the question of whether Congress should explicitly alter the preclearance review and, specifically, clarify the retrogression standard that the courts have read into the statute. ${ }^{212}$

208. $I d$.

209. Paula D. McClain \& Joseph Stewart, Whither the VRA After Shaw v. Reno: Advancing to the Past?, 28 Pol. SCI. \& Pols. 1, 25 (1995) ("Surely there is a threshold of racial and ethnic minority representation necessary to have the interests of these groups represented at all, and none of the advocates of influence districts consider the appropriate level of representation ... The limited research on racial minorities and agenda setting has found that they have little access to or influence on the policy agendasetting process ... Clearly, there are limits to the strategy of creating majority-minority districts, but the history of white representation of minority populations is not cause for optimism.").

210. Benson, supra note 72 (arguing that any effort to reauthorize Section 5 must include a strengthening of the retrogression standard that will allow for the preservation of majority-minority districts).

211. See supra text accompanying notes 62-72.

212. See Beer v. United States, 425 U.S. 130 (1976). 
The concept of retrogression as it relates to voting rights law was introduced by the Supreme Court in Beer v. United States. ${ }^{213}$ Specifically, the Court defined the non-retrogression rule of Section 5 to mean that "no voting procedure changes [in jurisdictions covered by Section 5] would be made that would lead to a retrogression in the position of racial minorities with respect to their effective exercise of the electoral franchise." ${ }^{214}$ Since then it has been modified, ${ }^{215}$ but, like some aforementioned relative Section 5 terms, its most frequent criticism is the vagueness of the standard.

Practitioners, academics, and the courts have lamented the difficulties of applying the retrogression standard. And since Congress has never formally articulated any response to the Beer decision, the responsibility has been left to the courts to clarify it - a responsibility they have not shouldered well. As one commentator notes, "[s]o little attempt has been made by the Court to articulate a definition or standard of retrogression that we can only catalog what is retrogressive and what is not." 216 This vagueness is exacerbated by the fact that the non-retrogression principle is an essential element of Section 5 cases, which are typically centered on redistricting issues. ${ }^{217}$

In particular, courts have had considerable difficulty determining what should be considered the "benchmark" plan, which is crucial in analyzing whether a new plan has a retrogressive effect compared with the original benchmark plan. ${ }^{218}$ The Supreme Court has held that the general standard for determining a benchmark plan under Section 5 is to compare the proposed voting practice against the existing voting practice. ${ }^{219}$ However, Karlan and others have highlighted the unreliability of those benchmark plans in

213. See discussion of Beer, supra text accompanying notes 34-36.

214. Beer, 425 U.S. at 141. (2003).

215. Reno v. Bossier Parish Sch. Bd., 528 U.S. 320 (1999); Georgia v. Ashcroft, 123 S. Ct. 2498

216. Frederick G. Slabach, Race, Redistricting and Retrogression in Mississippi after the 2000 Census, 68 Miss. L.J. 81, 87 (1998) (noting that courts have done very little to alter non-retrogression from its analysis in Beer); see also id. at 88-89 ("The Court's application of the Beer retrogression language illustrates the difficulty of identifying a normative principle or an articulable standard. In fact, the Court has not attempted to do so; it has been content to make case-by-case determinations and conclusory statements. The net result is that Justice Stewart's opinion in Beer has done for the Voting Rights Act what his concurring opinion in Jacobellis v. Ohio did for 'hard-core pornography'-the Court simply knows it when it sees it.").

217. See J. Philip Calabrese, Book Note, 35 Harv. J. On Legis. 289, 290 (1998) (referring to retrogression as important tool).

218. See generally Pamela S. Karlan, The Fire Next Time: Reapportionment After the 2000 Census, 50 Stan. L. Rev. 731, 741-53 (1998) [hereinafter The Fire Next Time] (discussing difficulties in determining benchmarks).

219. Holder v. Hall, 512 U.S. 874, 883 (1994). 
situations where the demographics in a jurisdiction have changed dramatically since the original benchmark plan was drawn, making it irrelevant and inapplicable for the current population. ${ }^{220}$ The Court has addressed this issue in part on more than one occasion, ${ }^{221}$ most significantly in Abrams $v$. Johnson, ${ }^{222}$ when it held that when a jurisdiction adds an electoral district, but the number of majority-minority districts remains the same, there is no retrogression. ${ }^{223}$ Karlan notes that Abrams "poses a set of unresolved questions," in particular determining the numerator and denominator for districting comparisons, ${ }^{224}$ as well as the questions over protecting certain types of districting proportions, ${ }^{225}$ as discussed in the previous section.

Apart from benchmark and comparison issues, another vague aspect to the retrogression standard involves questions of how to actually measure whether a change will have a retrogressive effect. Of specific concern is whether a court would deem a change that could decrease the turnout or registration rates of minority voters to be "retrogressive." If it were not deemed retrogressive, it invites the question of how much proof is needed to demonstrate that an election law change would depress the electoral engagement of minority communities to sufficiently show adequate retrogression. ${ }^{226}$

A third concern is the absence of any requirement that a court consider the presence of racially polarized voting in the examined jurisdiction when determining retrogression. This absence leads to further confusion, since the

220. Karlan, supra note 218, at 747. See also Errickson, supra note 36, at 2081 ("[T]he nonretrogression principle began to encounter problems during the period after 1990, the third decennial census after the passage of the Voting Rights Act. As states gained additional congressional seats, the baseline for retrogression shifted and became unclear."); Motomura, supra note 125, at 193 (“One limitation of Beer's retrogression test is its requirement that the decision-maker ascertain a status quo with which to compare the submitted change.").

221. See, e.g., Bush v. Vera, 517 U.S. 952 (1996).

222. 521 U.S. 74 (1997)

223. Id. at 91-94. In Abrams, the "benchmark" plan had 10 electoral districts with one majority Black district, while the challenged plan still contained one majority-minority district but had 11 total districts. Id. at 96-98.

224. Karlan, supra note 218, at 748-51 (arguing that "logic" suggests that "the ap propriate numerator for assessing retrogression is what the numerator in the prior plan would have been had the prior plan had the same denominator as the plan under review").

225. Id. at 752 (stating in exasperation, "Well, just how black would a new District 18 have to be to avoid retrogression?").

226. These questions are more eloquently articulated by Errickson, supra note 36, at 2059 (" $[\mathrm{H}]$ aziness around the non-retrogression principle exists primarily because the Supreme Court has yet to define clearly how to measure whether a minority group is going to suffer more severe vote dilution under a proposed districting plan."). 
presence of a racially polarized electorate can exacerbate potential problems with certain districting changes. ${ }^{227}$ Additionally, while some argue that there has been a decline in racially polarized voting in recent years, ${ }^{228}$ what is more certain is that there are regional variations affecting the degree of polarization in a specific area. This indicates that in some areas the presence of high polarization will combine with certain electoral changes to have a retrogressive effect on the minority voters in the jurisdiction, while in other areas the same electoral changes will have a significantly less harmful effect. $^{229}$ As such, a requirement that a court consider levels of racial polarization in evaluating changes under Section 5 , as it is required to do under Section 2, would help clarify the application of the retrogression standard. ${ }^{230}$

The above effects of the muddled retrogression standard are, in part, due to the fact that it is a product of case law, created in Beer and continually molded on an ad-hoc, case-by-case basis. But if Congress were to take responsibility away from the Court and attempt to both formalize and clarify the standard through amendments to Section 5, a second question emerges of what form a clarified retrogression standard should take.

Here again, empirical research could shed light on the best way to define a retrogression standard. Apart from that, Congress - in addition to the

227. Georgia v. Ashcroft, 123 S. Ct. 2498, 2518 (Souter, J., dissenting) ("Before a State shifts from majority-minority to coalition districts, however, the State ... must show not merely that minority voters in new districts may have some influence, but that minority voters will have effective influence translatable into probable election results comparable to what they enjoyed under the existing district scheme. And to demonstrate this, a State must do more than produce reports of minority voting age percentages; it must show that the probable voting behavior of nonminority voters will make coalitions with minorities a real prospect.") (internal citations omitted).

228. See The Future of Majority-Minority Districts, supra note 201, at 2209.

229. For a description of the effect that these regional variations have had on certain electoral changes, see $i d$. at 2218 ("Ten years ago, for example, a federal court in Ohio found that because of the low levels of racially polarized voting in that state, "black candidates have been repeatedly elected from districts with only a $35 \%$ black population.' In contrast, a study of South Carolina elections during roughly the same period found that the black voting age population had to be greater than forty-six percent to ensure blacks an equal opportunity to elect their preferred candidates.") (citing David Epstein \& Sharyn O'Halloran, $A$ Social Science Approach to Race, Redistricting and Representation, 93 Am. J. PoL. SCI. 187, 189 (1999)).

230. Georgia, 123 S. Ct. at 2518 (Souter, J., dissenting) ("Before a State shifts from majorityminority to coalition districts, however, the State bears the burden of proving that nonminority voters will reliably vote along with the minority, ... It must show not merely that minority voters in new districts may have some influence, but that minority voters will have effective influence translatable into probable election results comparable to what they enjoyed under the existing district scheme. And to demonstrate this, a State must do more than produce reports of minority voting age percentages; it must show that the probable voting behavior of nonminority voters will make coalitions with minorities a real prospect.") (internal citations omitted). 
aforementioned example of requiring a court to consider levels of racially polarized voting - could explicitly state what the comparative baseline should be when evaluating retrogression. ${ }^{231}$ One commentator has suggested that the courts be required to use proportionality as a retrogression baseline, evaluating a districting plan based on the change in the state's racial demographics, rather than comparing it to the previously enacted legal voting plan. ${ }^{232}$ Under this proposal, which would apply specifically to redistricting changes, a state's plan would have to adequately reflect the proportion of minority voters statewide and show that they have potential to be represented in some proportion that would reflect the relative size of their population. ${ }^{233}$ The court, similarly, would have to take into account the relative percentage of a jurisdiction's minority population when evaluating a proposed districting plan. ${ }^{234}$

There are two drawbacks to this sort of alteration to the retrogression standard. First, it is not clear how requiring proportionality would apply to non-redistricting changes under Section 5, such as changes in polling place locations or election procedures. Second, the U.S. Supreme Court explicitly rejected the idea of proportional representation in Johnson v. De Grandy. ${ }^{235}$ Angering the Supreme Court with an amendment to a renewed Section 5 is not a wise political move for Congress to attempt given the Court's present concerns threatening the general constitutionality of Section 5.

Another possibility for clarifying the retrogression standard is for Congress to explicitly list certain changes that would per se be deemed retrogressive. Congress could either list which changes it intends to be deemed retrogressive, or it could list certain evidence that, upon production, would be sufficient for a denial of preclearance.

An example of this would be evidence that a certain districting or election change would likely lead to a decrease in the electoral participation of minority voters. In other words, any change that is likely to lead to a decrease in the turnout or registration rates of minority voters would be per se retrogressive. Proponents of this change would then have the burden of showing that turnout or registration rates are not likely to decrease as a result

231. Errickson, supra note 36, at 2092-93.

232. Id. at 2092.

233. For more on this proposal, see $i d$. at 2092 ("If a state that contains only one majority-minority district faces a decrease in the percentage of its minority residents, that state could be obligated to continue providing the minority population with that one district in order to avoid backsliding under the nonretrogression principle.").

234. Id.

235. 512 U.S. 997 (1994). 
of the change, perhaps by presenting evidence that enacting the change in similarly situated areas did not produce a decrease in participation rates.

Of course, there are various factors that contribute to the increase or decrease of electoral engagement, and enacting this change could open a host of other uncertainties into litigation, such as how much of a decrease would have to be proven or disproved in order to overcome the presumption of retrogression. But at the same time, some research has shown that certain changes to apportionment plans do lead to a decrease in participation. In particular, some studies indicate that black voter participation increases in districts with high levels of black population, suggesting that moving black voters from majority-minority districts to districts where they comprise a smaller proportion of the population may lead to a decrease in their turnout rates. ${ }^{236}$ With further and more definitive research that certain changes are more or less likely to lead to a decrease in the electoral engagement of minority voters, advocates may be able to build a compelling case that Section 5 review should include an explicit requirement to block changes that could harm minority participation.

However, although a Congressional clarification of the retrogression standard may lead to a stronger Section 5, it would also codify the idea of retrogression as the way to evaluate Section 5 claims. ${ }^{237}$ While Congress arguably implicitly codified retrogression by choosing not to alter the standard in the more than twenty-five years since the Court created the standard in Beer $v$. United States, Congress is not barred from writing it out entirely and enacting a new standard for evaluating election changes in covered jurisdictions.

In this vein, some have suggested that replacing the retrogression standard with the vote dilution standard of Section 2 is the optimum way to both address the inconsistency between the two sections and potential constitutional concerns, ${ }^{238}$ while also strengthening the preclearance criteria. ${ }^{239}$

236. Joe Darden, Black Political Underrepresentation in Majority Black Places, 15 J. BLACK STUD. 100,111 (1984).

237. Several scholars have discussed the general problems with the retrogression approach. See, e.g., Errickson, supra note 36, at 2083 ("The current retrogression standard disadvantages black voters because it allows preclearance of any voting plan that does not dilute black votes more than the current plan.”); John C. Jeffries, Jr. \& Daryl J. Levinson, The Non-Retrogression Principle in Constitutional Law, 86 CAL. L. REV. 1211, 1214 (1998) ("[N]on-retrogression has obvious shortcomings. It does not cure existing evils; it only forbids new ones. Moreover, there is something unsettling in the patchwork regime it creates. [Certain election changes may be] lawful in one county but not in its neighbor.").

238. See Errickson, supra note 36, at 2092 ("[B]y eliminating the non-retrogression principle, states would be freed from the pointless exercise of seeking Justice Department preclearance for a plan that will 
The issue of formal incorporation has been a subject of great debate ${ }^{240}$ since the U.S. Supreme Court held in Bossier Parish $P^{21}$ that a violation of Section 2 is not a per se violation of Section $5 .{ }^{242}$ One commentator has even presented a detailed proposal of how such an incorporation could be structured. ${ }^{243}$

There is another potential dilemma that could emerge if Section 2 violations are automatically rejected under Section 5 preclearance evaluations. The political costs and subsequent ramifications of pushing for the incorporation would be extremely high, as it would greatly expand the level of inquiry the Justice Department would be required to exert in investigating preclearance submissions. This could lead the Court to reinterpret and weaken the Section 2 vote dilution standard in order to lessen the burden

not survive an equal protection challenge in the courts. In short, elimination of the non-retrogression principle as the criterion for preclearance would simply recognize what the Supreme Court has already acknowledged: that the real battle over discriminatory reapportionment plans has shifted to section 2 claims.").

239. Various commentators have discussed incorporating Section 5 and Section 2. See, e.g., Motomura, supra note 125, at 196 (arguing that "vote dilution, rather than the retrogression test, offers a more reliable guide to the substantive principles that have developed under section 5."); see generally Way, supra note 127; Winke, supra note 92; Errickson, supra note 36.

240. Mark E. Haddad, Note, Getting Results Under Section 5 of the Voting Rights Act, 94 YALE L.J. 139, 158-62 (1984) (noting that incorporating section 2 into section 5 will "return section 5 to its proper role as an agent for the elimination rather than the perpetuation of racial vote dilution"); Way, supra note 127, at 1473 (noting that incorporation of the Section 2 standard into Section 5 is needed to effectuate broad remedial purpose of Voting Rights Act). But see Recent Case, 109 Harv. L. Rev. 681, 686 (1996) (noting that incorporation of Section 2 into Section 5 would exacerbate "serious and unwarranted federalism costs" to states).

241. 520 U.S. 471 (1997).

242. Id. at 483-84. For further discussion of how Section 2 violations were found to violate Section 5 prior to 1997, including the Senate endorsement of that interpretation and its incorporation into the Attorney General's regulations, see Laughlin McDonald, The Quiet Revolution in Minority Voting Rights, 42 VAND. L. ReV. 1249, 1287-91 (1989).

243. See Way, supra note 127 , at 1480-81.

$[T]$ he burden should be on the Justice Department to prove that a submitted plan clearly violates Section 2, rather than on the jurisdiction to prove that plan does not clearly violate Section 2. In the context of a Section 2 suit, it is very difficult for a jurisdiction to prove the negative- that it has not violated Section 2; a presumption of discrimination thus ... decreases the likelihood that a submitted plan will be found to violate Section 2. Second, once the Justice Department decides that a voting change potentially violates Section 2 , the final decision should be made by an Administrative Law Judge in an expedited hearing rather than by the Justice Department. . . An ALJ would be able to serve as a disinterested party and provide more assurance that a decision will not be based on partisan grounds. The expedited hearing, along with strict evidentiary deadlines, could also potentially reduce some of the delays currently present under Section 5 . 
placed on the DOJ. The result, of course, would be a weakening of both the "shield" and the "sword" of the VRA. ${ }^{244}$

\section{Five Priorities for 2007}

The above discussion presents an overview of some of the most salient issues that can be expected to be involved when, and if, Congress considers amending Section 5 in 2007. While the attempt is meant to be as comprehensive as possible, it is still by no means conclusive. Based on the foregoing analysis, there are five priorities that advocates, academics, and observers should focus on in gearing up for the legislative battle over the reauthorization of Section 5 .

1. Collect Evidence of Discriminatory Election Policies and Procedures That Will Ensure That Section 5 Will Pass Constitutional Scrutiny.

Concerns about the constitutionality of Section 5 are heightened after the Supreme Court's recent decision in Boerne, and ensuring that the provision is supported with sufficient evidence of discrimination is essential to confirming it will be upheld upon renewal. Thus, at the center of any renewal strategy should be discussions of what sorts of evidence will be most beneficial to the reauthorization, or whether it is worth altering Section 5 to increase the likelihood of its constitutionality.

Various commentators have made suggestions as to what sorts of evidence of continued discrimination in covered areas, and how much, is necessary to justify Congressional reauthorization of Section 5. ${ }^{245}$ One commentator has proposed that evidence of racial bloc voting - among other indicators of minority under-representation - could be presented as a proxy for discrimination. ${ }^{246}$ Others have stressed the need for a showing of broad patterns of various types of discrimination. ${ }^{247}$

Also relevant to consider are legislative strategies to alter Section 5 that would increase the likelihood of its survival to a constitutional challenge. Bernard Grofman, a frequent expert witness in voting rights cases and long

244. But see id. at 1443-44 ("Without incorporation, a jurisdiction could enact changes with a clear discriminatory 'result.' Section 5 could be used only as a shield, with which the Justice Department and the judiciary could block only voting changes that make minority voters worse off. With incorporation, ... a jurisdiction could not enact a change that is clearly discriminatory, even if minority voters were not worse off under the new plan. Incorporation transforms Section 5 into a sword, enabling the Justice Department and the judiciary to force jurisdictions to make greater strides to eradicate voting discrimination.”).

245. See discussion supra Part II.A. accompanying notes 88-92.

246. See Winke, supra note 92, at 101.

247. See generally Karlan, supra note 93, at 739. 
time advocate for the VRA, supports exploring the possibility of limiting Section 5 preclearance to redistricting changes. ${ }^{248}$ Moreover, Victor Rodriguez, an attorney with MALDEF, has indicated that other attempts to reduce the spread of Section 5, such as maintaining its temporary nature or placing more limits on which jurisdictions are covered, would boost the probability of its constitutionality. ${ }^{249}$

2. Emphasize the Symbolic, Historical, and Practical Importance of Preserving Section 5.

It is important that any reauthorization effort emphasize the general symbolic, historical, and practical importance of preserving Section 5. This includes public information campaigns aimed at elected officials at all levels, as well as groups and sectors that would be negatively affected if Section 5 is allowed to expire. On a symbolic level, such a campaign would involve a message about the sacrifices made to enact Section 5 and evidence of the vast number of discriminatory election laws and procedures that would have been enacted were it not for the Section 5 "shield." This could include, for example, a list of what changes were denied preclearance because they would have a retrogressive effect on minority voters, but that would have withstood a Section 2 and constitutional challenge and been enacted without Section 5 protection. ${ }^{250}$

It is also important, on a practical level, to illustrate the litigation costs that would be imposed by a predictable increase in Section 2 claims that would be filed as various advocate groups and individual citizens seek to prevent areas from enacting discriminatory changes and dilutive apportionment plans. Section 5 is a complementary and necessary component to the Voting Rights Act, and any strategy geared towards its renewal must be crafted to stress this.

3. Clarify an Appropriate Definition of Districts Likely to Elect Minority Candidates of Choice.

Advocates and academics must discuss ways to elucidate certain, currently unclear, but very vital, terms relevant to Section $5 .{ }^{251}$ This specifically involves discussing what are appropriate definitions of majority-

248. See Grofman, supra note 138.

249. Rodriguez, supra note 75 , at 816.

250. See Jeffries \& Levinson, supra note 237, at 1214 ("Under the Voting Rights Act, Section 5 nonretrogression complements the Section 2 prohibition on vote dilution. In some situations, however, nonretrogression is the only viable enforcement mechanism. ... [It] provides some protection to minority voters without threatening the wholesale federalization of the structure of state and local governments.").

251. See supra Part III.A. 
minority, influence, and coalitional districts, and whether Congress - either in the text of the legislation or in the legislative record - should clarify these definitions. Such clarification would be highly beneficial from both a litigation and public information context, since, among other things, it would eliminate preclearance problems that are based on misunderstandings of the appropriate definitions. ${ }^{252}$ A component of these definitions could be an explanation of the likelihood that, given certain degrees of racially polarized voting, a minority candidate of choice can be elected from that district. Similarly, the definitions can also attempt to address just how much "influence" minority voters will have over the outcome of various local and district-wide elections. ${ }^{253}$

4. Discuss Whether Section 5 Should Encourage the Creation or Preserve the Presence of Certain Types of Districts.

Under the current interpretation of Section 5, the Court has allowed local jurisdictions to decide which types of districting best fit their needs. ${ }^{254}$ As such, there is little required federal oversight of districting changes. Congress has the power under Article I, and the Fourteenth and Fifteenth Amendments of the Constitution, to respond to the Supreme Court's interpretation and create clear, meaningful protections against changes in election laws that harm minority voters. Such a response should involve discussions over whether Section 5 preclearance should encourage one type of district over another.

Advocates and academics currently have time to pursue research that can attempt to determine the specific benefits and drawbacks of certain districts and districting changes. Such research could illuminate whether, for example, the participation rates of minority voters decrease when they are redistricted out of a majority-minority district and into an influence or coalition district. It would also enable Congress, advocates, and academics to engage in an informed discussion over what sort of political power is worth protecting, and which types of districts can enable or disable that protection.

252. See supra discussion of Arizona redistricting effort, accompanying notes 143-46.

253. See Butler, supra note 146, at 1464-65 (predicting what will happen if Congress continues to cede the power to define these terms to the courts: "When the Supreme Court is actually faced with defining a 'black district' for purposes of measuring retrogression, I predict that it will adopt a 'bright-line test'- perhaps concluding that a black district is any district in which blacks are the majority of the voting age population and any specific district in which a black support black candidate has been elected, regardless of the actual percentage of the district's population that is black.”).

254. Georgia v. Ashcroft, 123 S. Ct. 2498 (2003). 
5. The Retrogression Standard: Should It Be Clarified, Strengthened, or Replaced with a Section 2 Vote Dilution Test?

Closely linked to the debate over what districting schemes a renewed Section 5 should promote or protect is the question of whether Congress should explicitly adopt and clarify the retrogression standard. ${ }^{255}$ Because much of the confusion about the retrogression standard has been over what constitutes retrogression, Congress can take this opportunity to explicitly define which electoral changes should be deemed to be retrogressive in purpose or effect, in violation of Section 5, as opposed to allowing the courts to struggle with defining an increasingly vague standard. And while a Congressional definition would effectively codify Beer, it would also give Congress the power to decide what a retrogressive effect or purpose would look like.

An explicit retrogression standard that might win the support of conservative legislators could, for example, acknowledge the importance of influence districts while also emphasizing the dangers of using them to replace majority-minority districts. This standard could state that a jurisdiction could reduce the minority voting age population from above $55 \%$ to under $55 \%$ only where it can prove either that racially polarized voting is nonexistent in the area or that turnout of minority voters will not decrease as a result of the change. Alternatively, Congress could mandate that Section 5 jurisdictions proposing any change must show that the change will not reduce the registration or turnout rates of minority voters.

In addition, doing away with the retrogression standard altogether and replacing it with the vote dilution standards of Section 2 is also a viable option. ${ }^{256}$ Under this proposal, Congress could require a jurisdiction covered by Section 5 to show that a proposed change would not violate the vote dilution standards of Section 2 of the Voting Rights Act in order to obtain preclearance. ${ }^{257}$ This change would have the best chance of withstanding a Supreme Court challenge because it would directly respond to Justice Kennedy's concern that a plan precleared under Section 5 might violate Section 2 or the Fourteenth Amendment. ${ }^{258}$ A countervailing concern,

255. Beer v. United States, 425 U.S. 130 (1976).

256. See supra discussion of incorporating Section 2 with Section 5 accompanying notes 239-44.

257. See Thornburg v. Gingles, 478 U.S. 30 (1986) (holding that the presence of three factors in an electoral plan - racially polarized voting, a geographically concentrated minority, and an opposing racial bloc that interferes with the minority's power-constitute necessary preconditions for proving a violation of Section 2).

258. Georgia, 123 S. Ct. at 2517 (Kennedy, J., concurring). 
however, is that the Court might respond by weakening the standard under Section 2, thus weakening the entire VRA.

\section{CONCLUSION}

The above overview of issues, and the "top five" suggested priorities, are meant as a starting point to spark debate and discussion over how to approach and shape the reauthorization. As 2007 nears, the time is ripe for voting rights supporters in the government, academic, and advocacy worlds to begin studying ways to ensure the longevity and strength of the provision. Over the next few years, supporters must unite behind an agenda that will renew and strengthen the VRA and ensure the Act remains a real and robust part of this country's election law and voting rights history. 